\title{
Hydro-Stratigraphic Conditions and Human Activity Leading to Development of a Sinkhole Cluster in a Mediterranean Water Ecosystem
}

\author{
Stefano Margiotta ${ }^{1}$, Gabriele Marini ${ }^{1,2}{ }^{,}$, Sergio Fay ${ }^{3}$, Francesco M. D'Onghia ${ }^{4} \mathbb{D}$, Isabella S. Liso ${ }^{5}$, \\ Mario Parise ${ }^{5, *(D)}$ and Maurizio Pinna ${ }^{1,2}$ (D) \\ 1 Department of Biological and Environmental Sciences and Technologies, DiSTeBA, University of Salento, \\ 73100 Lecce, Italy; stefano.margiotta@unisalento.it (S.M.); gabriele.marini@unisalento.it (G.M.); \\ maurizio.pinna@unisalento.it (M.P.) \\ 2 Research Centre for Fisheries and Aquaculture of Acquatina di Frigole, DiSTeBA, University of Salento, \\ 73100 Lecce, Italy \\ 3 Photography and Coastal System Monitoring Laboratory, University of Salento, 73100 Lecce, Italy; \\ natura.pro@tiscali.it \\ 4 Museo Marino Artistico (MuMART), 70126 Bari, Italy; fmdonghia@alice.it \\ 5 Department of Earth and Environmental Sciences, University Aldo Moro, 70126 Bari, Italy; \\ isabella.liso@uniba.it \\ * Correspondence: mario.parise@uniba.it
}

check for updates

Citation: Margiotta, S.; Marini, G.; Fay, S.; D'Onghia, F.M.; Liso, I.S.; Parise, M.; Pinna, M. HydroStratigraphic Conditions and Human Activity Leading to Development of a Sinkhole Cluster in a Mediterranean Water Ecosystem. Hydrology 2021, 8, 111. https://doi.org/10.3390/ hydrology8030111

Academic Editor: Mahmoud Sherif

Received: 28 June 2021

Accepted: 26 July 2021

Published: 31 July 2021

Publisher's Note: MDPI stays neutral with regard to jurisdictional claims in published maps and institutional affiliations.

Copyright: (c) 2021 by the authors. Licensee MDPI, Basel, Switzerland. This article is an open access article distributed under the terms and conditions of the Creative Commons Attribution (CC BY) license (https:/ / creativecommons.org/licenses/by/ $4.0 /)$.

\begin{abstract}
Salento Peninsula (Apulia, southern Italy) is characterised by many active sinkholes, which represent the main geological hazard. The stretch of coastline between the village of Casalabate and Le Cesine wildlife reserve is highly affected, with a system of dunes separating the low beach from extensive wetlands, which were subject to uncontrolled urban development after reclamation. The overall morphology is characterized by flat topography, whilst from a hydrogeological standpoint, the mixing of inland freshwater with advancing brackish water favours the higher aggressivity with respect to soluble rocks, and the development of enhanced dissolution (hyperkarst). The relict landscapes within the protected areas still allow for the recognition of actively occurring sinkholes, which cause damage to houses, the road network and infrastructures. In this article the case of Aquatina di Frigole is described, where in the last 15 years numerous sinkholes have formed, with the processes still in rapid evolution. Detailed surveys allow for to identification of the mechanisms of sinkhole formation (suffusion sinkholes), the deriving cluster, and the main hydrogeological links among the different water bodies in the area. Acquatina di Frigole provides an excellent natural laboratory to observe development and evolution of sinkholes, and their relationships with the stratigraphic and hydrogeological elements.
\end{abstract}

Keywords: Acquatina di Frigole; NATURA 2000 site; Apulia; coastal geomorphology; karst hydrogeology; sinkhole; Cymodocea nodosa

\section{Introduction}

Sinkholes [1-3] are often at the origin of damage and problems to public safety in karst environments [4-8]. They are among the most frequent geological hazards in karst terrains worldwide [9-12] and are typically produced at the surface circular to elliptical landforms, characterized by sub-vertical to vertical walls and depths ranging from some cm to tens of meters. The solubility of carbonate and evaporite rocks with the development of karst processes is at the origin of sinkhole formation [2,3], whose mechanisms may develop in different ways according to the local stratigraphy and permeability, the groundwater flow and in fucntion of the modality of outcrops of soluble rocks (directly at the surface, or covered by other, soluble or insoluble, materials). With a variety of mechanisms of 
formation, sinkholes are increasingly affecting many karst areas around the globe, with serious consequences to human society and severe economic losses [13-20].

The Apulia region of southeastern Italy is an elongated peninsula, with about $900 \mathrm{~km}$ of coasts that are strongly appealing for tourists and which therefore host a high number of visitors during the summer, especially along the coastal areas. The beauty of the landscape is often related to karsts and caves, which are therefore among the main elements to develop dedicated pathways and geosites in order to offer to tourists a view on the geological and morhological features of the area [21]. In this regard, geotourism [22-24] is definitely gaining an important space in Apulia [25-30].

Due to the diffuse carbonate oucrops, the region is severely affected by sinkhole occurrences, related to karst caves as well as man-made cavities [31,32]. In Apulia, sinkholes represent the most significant geological hazard, together with slope movements affecting the several hundreds of kilometers-long coastlines and the inner Daunia Apennine at the boundary with Campania. In this century, the frequency of such events has definitely increased, with a peak in 2009 to 2010 [33-35]. The documented events do not depict the whole situation, since many features are not reported by landowners. To further testify to the frequency and importance of these phenomena in the region, large-size sinkholes have also been detected offshore during oceanographic surveys [36].

Along the Apulian carbonate coasts, the frequency and distribution of ground instability are controlled by the morphology (beaches vs. cliffs), the presence of different lithotypes (calcarenite, sand, limestone, etc.), karst caves and man-made cavities [37]. Among the possible failures, sinkholes may significantly result in influencing the evolution of the coastline [38-44]. As a consequence, they locally become the main factor in the overall configuration of the coast, shaping bays or inlets. This especially happens at low-lying coasts as at Torre Castiglione [45,46], on the Ionian side of Apulia, where the sinkhole evolution is strongly controlled by tectonics and by the mixing processes between fresh and brackish water. As is well known in the karst literature, mixtures deriving from the encounter of waters with different characters result in a strong increase in the karstification process due to the higher aggressivity of the resulting solution toward the soluble rocks (hyperkarst) [47-50]; this is the reason why dissolution is often strongly enhanced along the coastlines, giving rise to peculiar karst landforms [38,51-56].

Going back to the description of sinkhole processes along the Ionian coastline of Apulia, the Palude del Capitano area, south of Torre Castiglione, shows an advanced evolution stage, with wide basins linked through underwater connections only partially explored so far [57-62]. On the Adriatic coastline Le Cesine is a $3 \mathrm{~km}^{2}$ swamp environment in Early Pleistocene calcarenites. Delle Rose and Parise [63] reconstructed its evolution, which started with the formation of individual sinkholes, which later coalescence and are brought to the present situation. Whatever the characters and typology of the coast, the sinkhole hazard should deserve higher attention, with the goal to reduce its risk to society $[6,29,37,64-70]$. This is certainly the case of the eastern Salento coastline (Figure 1) between the village of Casalabate and Le Cesine, in which the localities of Casalabate, Torre Rinalda, Spiaggiabella and Torre Chianca have a long history of damage [29,37].

To assess the potential danger from coastal sinkholes, to better comprehend the evolution of the process and to verify the likely effects on the environment, the main predisposing factors must be recognized and monitored. In this article, we present an integrated methodology, which is a combination of detailed stratigraphic and geological data with the available hydrogeological information, and the ecology contribution. All of this is integrated by a long archival research that made it possible to find historical maps and to document the man-made works done in the past. This is a remarkable aspect, since in many cases the loss of memory of how man has changed the natural landscape results in incorrect interpretations of the procesess nowadays at work. Based upon such an approach, the main goals of this contribution are addressed toward the above points, and particularly to document the recent evolution (last 15 years) of sinkholes along a stretch of the Adriatic coast, which is quite important for the touristic development of the area. Such 
a documentation is an essential element in the assessment process of sinkhole susceptibility and hazard, and in the definition of actions for mitigating the related risks. At this aim, we illustrate the case of Acquatina di Frigole, a protected area including a remarkable swamp where a number of sinkholes is presently evolving.

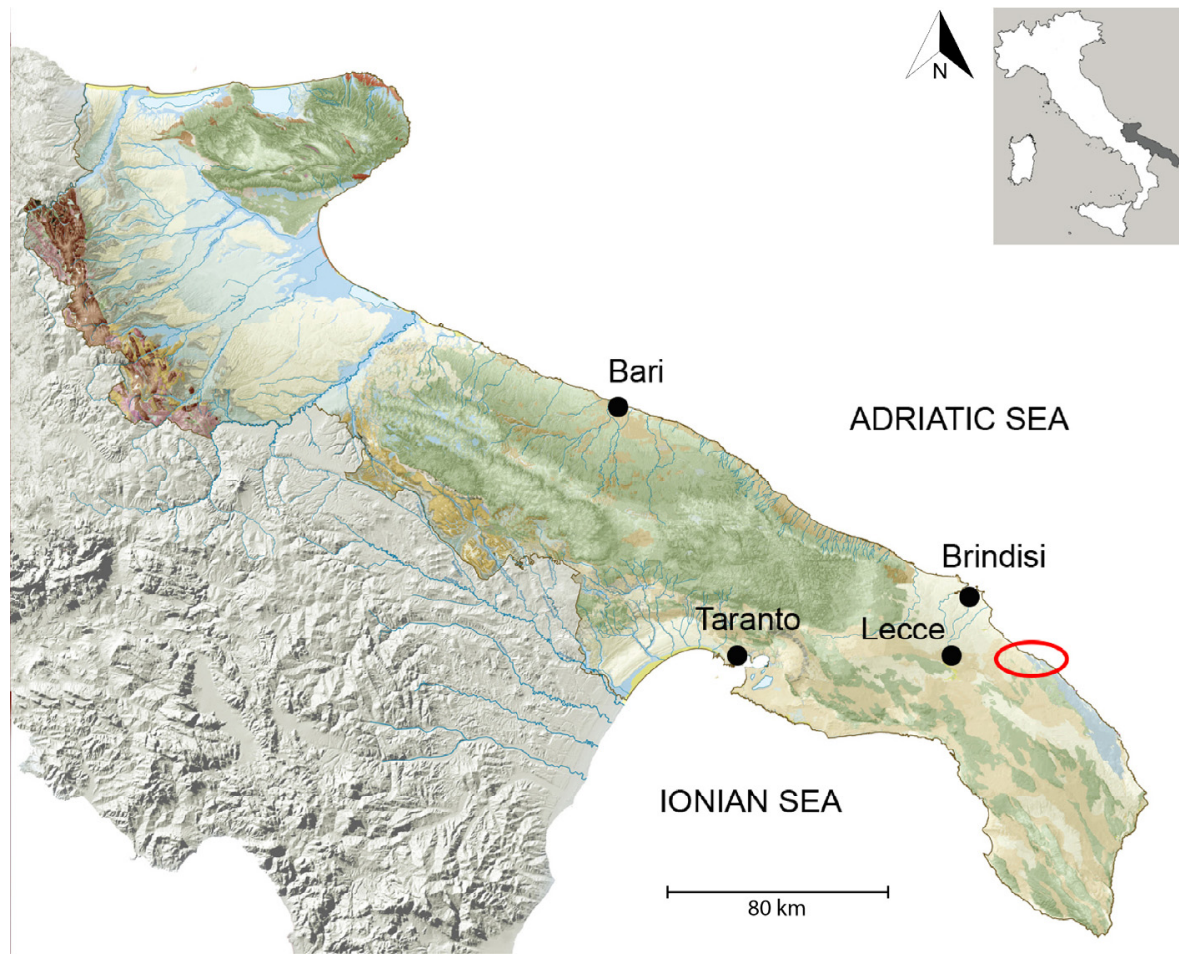

Figure 1. Shaded relief of Apulia, southern Italy, showing the location of the Acquatina di Frigole lagoon (red ellipse) in the Salento peninsula.

\section{Materials and Methods}

Activities carried out in the present article covered a wide range of actions, starting from historical research in local archives, aimed at finding documents and maps to testify the different steps in the process of land reclamation along the Adriatic Apulia. Even though the issue is of interest for both the local cultural heritage and the health problems in the area as well, many documents had to be scrutinized with detail to reconstruct the history. This was done at the Archive in Lecce, but also through the detailed analysis of old topographic maps by the Italian Geographical Army Institute (IGM). This is a very important part of the study, since the present evolution of the landscape is definitely occurring because of the past human works; as for many other types of geological hazards [71,72], keeping memory of the past events, especially in relation to human activities, is fundamental for a proper understanding of the processes working at present.

At the Acquatina di Frigole lagoon, the ecological part of the study was carried out through a number of surveys and observations, aimed at defining the vegetal species therein present and their main characters in the function of the development of the observed karst processes. Geology and hydrogeology were explored through a wider scale survey, in order to gain the best possible comprehension of the geological-structural setting. For this goal, outcomes from the field surveys were integrated by analysis of the available boreholes in the area to define to the best of our knowledge the real stratigraphic and hydrogeological setting in the area.

A multi-temporal analysis was performed on the orthophotos of the Acquatina di Frigole lagoon, from the years from 2006 up to 2019, when extensive work in the field was carried out to check the stages of development of the sinkholes. The orthophoto collection was also used to measure the main features of sinkhole morphometry in the plan (diameter, 
area, perimeter) and to assess their rate of widening and/or of coalescence. In the field, it was also possible to measure the depth of a selection of the sinkholes.

In February 2019, an unmanned aerial vehicle (UAV; DJI Phantom 4 pro) was used to fly over the area, at a height of $60 \mathrm{~m}$, producing a further orthomosaic with a resolution of 1.57/pix. In July 2019 a R.O.V. (Remotely Operated Vehicle; BLUROV model by BluRobotics) was used to investigate the Acquatina di Frigole lagoon. The vehicle was equipped with a full HD underwater camera, termometer, singlebeam echo sounder, and GPS (GARMIN ECHO MAP 72sv). This instrumentation was used to follow in the Acquatina di Frigole lagoon no. 5 continuous survey lines (labeled as tr01, tr02, tr03, tr04 and tr05) parallel to the coast, whilst additional no. 5 survey lines (tr06, $\operatorname{tr} 07, \operatorname{tr} 08, \operatorname{tr} 09$ and tr10) were carried out in the direction perpendicular to the coastline. Overall, about $1 \mathrm{~km}$ was surveyed in this way. The ROV was also equipped for video registration, but this was only locally possible, due to the high turbidity of the water, deriving from the movement of the operator guiding the ROV, which resulted in very poor visibility.

During the survey, along 4 surveyed stretches (respectively with length of $97 \mathrm{~m}, 274 \mathrm{~m}$, $310 \mathrm{~m}$ and $304 \mathrm{~m}$ ), the depth, water temperature and georeferenced location were recorded. The collected data indicated a maximum depth of $1,2 \mathrm{~m}$ in the basin, while the minimum depth is only $0.3 \mathrm{~m}$. The water temperature is in average $29.7^{\circ} \mathrm{C}$ (minimum value $29.4^{\circ} \mathrm{C}$, maximum $30.2{ }^{\circ} \mathrm{C}$ ) at the deepest sites, and slightly higher (average $30.6^{\circ} \mathrm{C}$ ) in the less deep areas.

\section{Regional Setting}

Salento (Figure 1) is characterized by diffuse karst landscapes, with collapsed sinkholes (vore or spunnulate in the local dialect) [73] as the most typical landform. A sinkhole's size becomes notable due to coalescence of individual features $[29,37,46,63,74,75]$. The geological setting of this region [76-82] comprises a Mesozoic carbonate sequence, which hosts the main aquifer and is covered by Paleogene, Neogene and Quaternary deposits, where shallow water tables are present and severe problems of marine intrusion along the coasts are registered $[83,84]$.

The hydrogeological characteristics of the Salento Mesozoic carbonate aquifer allow the marine waters to penetrate the subsoil of the entire territory; these invading marine waters connect the Ionian with the Adriatic Sea, forming a single underground water body, which is at the origin of the severe problems of marine intrusion [85-89].

Meteoric waters infiltrate the subsoil in concentrated form through sinkholes and/or fractures and/or in a diffuse manner when encountering the more porous geological formations. At the base level of freshwater (the sea), outflow occurs along the coast, both in diffuse and concentrated form (springs) [90]. Among the springs, the most important are Chidro [91] and Tara [92] on the Ionian side and Idume and Giammatteo on the Adriatic coast [93], together with the sulphurous springs at Santa Cesarea further south [94-96].

The hydraulic behaviour of this part of Salento, characterised by high heterogeneity due to fractured and karstified linestones and the widespread presence of sinkholes, results in channelized flow regimes and fast groundwater flow and transport. The coastal and karst nature further exacerbates the evidence of serious implications on groundwater quantity and salinization, due to climate change and human-related pressures, as a consequence of the overexploitation of the resources for agricultural and domestic activities [81-83,97-107].

The shallow aquifers, represented by Oligo-Mio-Plio-Pleistocene sedimentary deposits, are of difficult geometric definition, with sediments characterized by extremely variable types and degrees of permeability: generally permeable by porosity and secondarily by fractures, they can also be partly affected by karst caves or networks, due to the carbonate nature of the clasts. The degree of porosity is conditioned by frequent and sudden changes in the respective percentages of the grain size components, which is why the aquifers overlap aquicludes or pass both laterally and vertically to aquitards.

Geomorphologically, the Salento peninsula is a low-elevated landscape composed of Pleistocene terraces, bounded by NW-SE and NNW-SSE scarps extending from the sea level 
to altitude of $160 \mathrm{~m}$ a.s.l. The marine terraces were produced, since the Middle Pleistocene, by the combined effects of regional uplift and glacio-eustatic sea level changes [54-58] and are overlain by thin calcareous sandstones, locally associated with dunes.

Long stretches of both the Ionian and Adriatic shorelines are dominated by sandy beaches and dunes, alternated to small calcarenite promontories. The latter are covered inland by recent swamp deposits (clays and silts) and by karst residual materials. The main landforms (shorelines, scarps, divides) appear to be strongly controlled in their development by the tectonic lineaments $[45,46,63]$. At a smaller scale, even minor karst coastal landforms are influenced in their spatial distribution by the main discontinuity systems within the rock masses [108]. The Holocene sea-level rise worked in originating many marshes and lagoons along the Salento coastlines [25,37,109-112].

Eastern Salento is characterized for over $35 \mathrm{~km}$ by short sandy beaches, bounded by small rock promontories and inland by dunes, progressively disrupted by anthropogenic actions. The dune system separates the beach from the extensive wetlands occupying morphological depressions produced by slight undulations of the bedrock (nucleus of syncline in the Miocene sediments) $[29,90,113,114]$.

The Holocene deposits cover the Miocene-Pleistocene carbonate bedrock [111,114,115]. Freshwater availability favoured the colonization of this area, as documented by recognition, within the Holocene aeolian deposits, of three units: mid-Holocene, Greek-Roman and Medieval age [116]. In the different epochs, alternating stages of mild climate (Bronze Age) and of declining vegetation cover [117], brought also to intense phases of alluviation, and to later renewal of the natural vegetation, probably to be linked to abandonment of rural areas due to the unhealthy environment [117]. In the post-Roman period, the Saracen incursions and the Norman occupation resulted in depopulation of the area [118]. During the Middle Ages, a renewal of agriculture is testified by the sharp decline of shrubland and the high presence of cultivated plants [117]. Later on, between the 15th and 18th centuries, the settlements were scattered because of the Turkish and Saracen incursions, with fortified farmsteads and coastal towers. The population lived upon sheep breeding, cereals and olive cultivation [119], but the economic development was limited by the unhealthy swamps along the coast and the spreading of malaria. Wide abandoned areas, with marshes of limited size that dried up during the dry season, were reported by several authors at the beginning of the Italian Kingdom [120,121]. Libertini [122] identified many coastal marshlands along the Adriatic coast and pushed toward their transformation into agricultural fields through reclamation works. During the first decades of 20th century, wide sectors of the Salento coastlines were actually reclaimed [123,124]. Since the beginning of the 1970s, many coastal marshlands became to be occupied with vacation houses, leading to an uncontrolled urbanization, and, at the same time, originating a highly fragmented landscape, with swamp relicts in the protected areas (Le Cesine, Acquatina di Frigole, Regional Park "Bosco e Paludi di Rauccio") and intervening large sectors occupied by houses, where the original morphological elements of the karst landscape had been cancelled.

\subsection{The Acquatina di Frigole Site: History}

Geographically, the Acquatina di Frigole lagoon is located northeast from the city of Lecce, just north of the Marina of Frigole. Its present configuration (Figure 2) is the result of the superimposition on the natural elements of significant reclamation works that essentially had a two-fold purpose: hygienic, for the eradication of malaria, and economic, for the exploitation of land to be used for agriculture and fishing. 


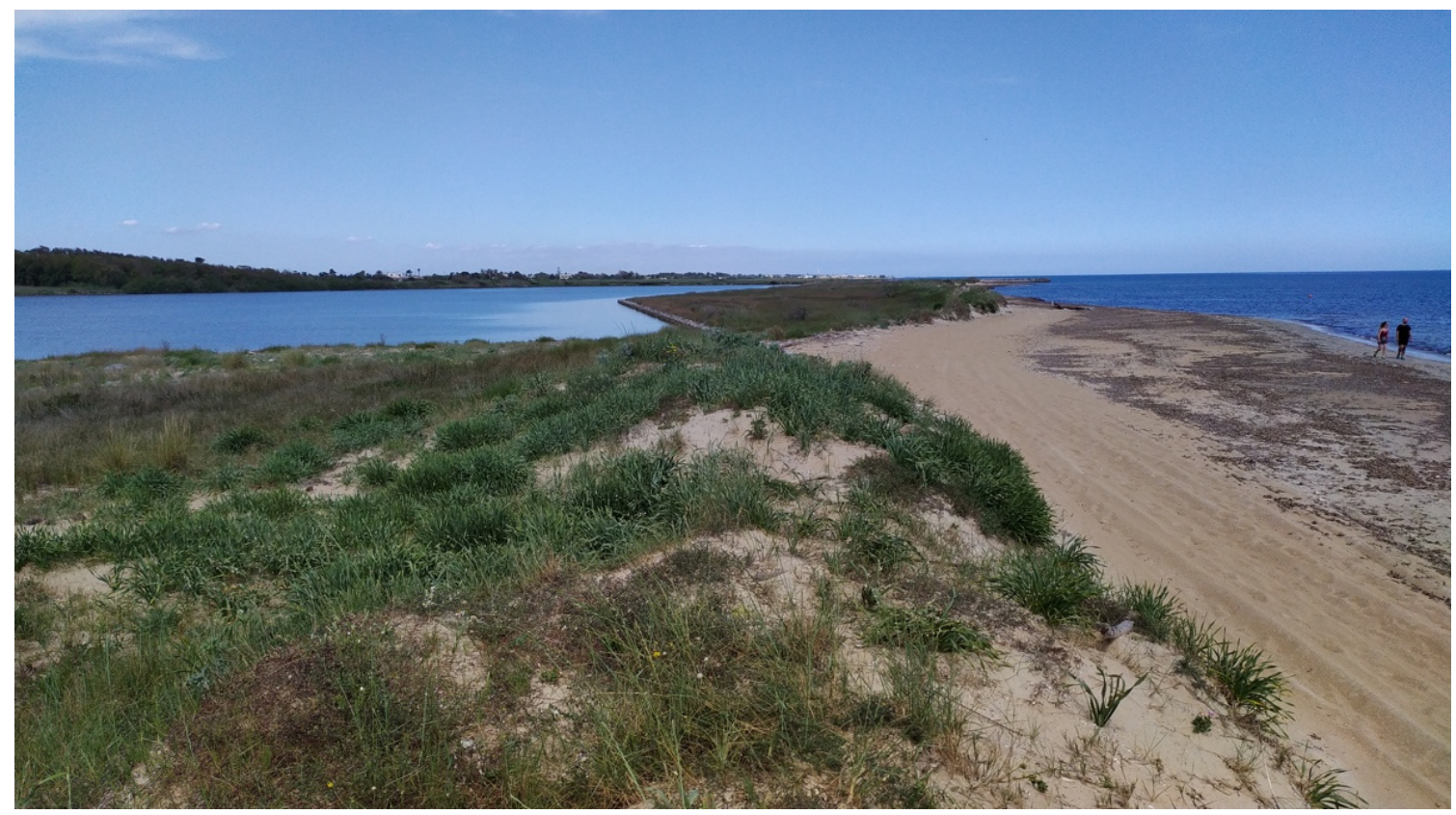

Figure 2. General view of the Acquatina di Frigole lagoon looking to the northwest.

The first attempts to reclaim the land started in 1870 by Federico Libertini, who owned most of the land between Torre Veneri and Torre Chianca. Libertini's works consisted of the construction of a network of canals leading into the sea and of the Acquatina di Frigole lagoon itself, an overall system which was intended to drain the waters from the wide marshlands. However, soon, the reclamation works turned out to be too demanding for Libertini, and he had to abandon such challenge, and turned down to die in poverty. Reclamation of the marshlands became again a priority of the government in 1900 when Luigi Libertini, head of the provincial technical office, planned the drainage of wide sectors, including Acquatina. The water was conveyed directly to the sea through canals when the bottom of the marshland was above the sea level. If, on the other hand, it was below sea level, as at Acquatina, the canals conveyed the waters into two tanks, one of arrival and the other of discharge from which, through a pumping machine, the same waters were poured into the sea [122] (Figure 3).

Tree species in the surrounding areas were selected based upon their capacity to absorb the remaining water and facilitate soil cultivation. This reclamation system actually turned out to be ineffective because the channels intersected the surficial aquifer, so that, when the dewatering machines stopped working, the water table returned quickly to the initial level. In the early 1920s, therefore, the landscape was still characterized by extensive marshlands, and malaria was fairly widespread $[125,126]$; even the attempt to eradicate the disease by sending into the Acquatina water thousands of Gambusia affinis (Baird \& Girard (1853)), an exotic species from America that had the characteristic of feeding on mosquito larvae, failed [124]. In 1921, the Opera Nazionale Combattenti (ONC) undertook the management of coastal areas (Acquatina di Frigole included) and entrusted Franco Cannaviello with the task of studying their nature to enhance them. Cannaviello concluded that the Acquatina di Frigole lagoon should be connected to the sea through a mouth. Finally, he argued that the lagoon thus built could have been an excellent fishing reserve. The failures of mechanical drying, the impossibility of filling the swamp due to the enormous quantities of materials needed and, on the other hand, the prospect of creating a less suitable environment for proliferation of mosquitoes through the salting of the marsh environment, in addition to the possibility of having an economic advantage from the use of the lagoon as a reserve for fishing, convinced the ONC technicians to pursue this idea. 


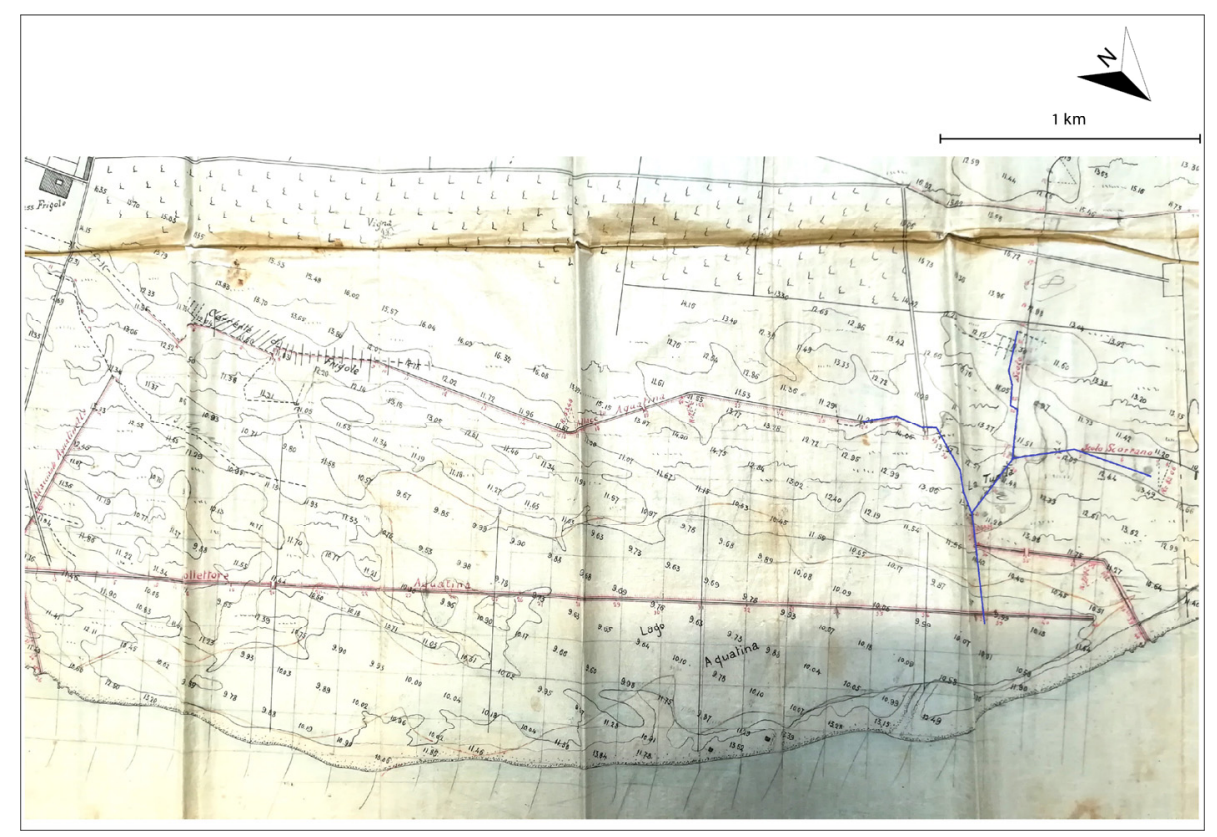

Figure 3. Extract of the project dated 19 July 1900 (signed by Eng. Luigi Libertini, Gaetano and Giulio Bernardini and presented by Eng. Fiorentino, head of the Civil Engineer, in April 1903; source: Envelope 26, Fasc. 126, State Archive of Lecce). On the right side of the map, the path designed for the Giammatteo River is visible. Originally the river consisted of three branches (here evidenced with blue lines), gathered in the area called "la tunda", which ended directly in the Acquatina di Frigole lagoon. The project instead provided that the mouth was subject to a canalization that went around the Acquatina di Frigole lagoon and ended at sea south of the Torre Chianca.

In 1931 the project was therefore ready for the rehabilitation of the Acquatina swamp through the deepening of its central part, filling of the lateral sectors that were shaped with squared stones, connection of the large swamp with the small one through a canal and above all through the communication of the swamp with the sea through two outlets of appropriate width and depth. In 1936, thanks to the employment of over 450 workers a day, the reclamation work was completed: the present configuration was reached only at the end of World War II, with the arrangement of the Giammatteo River outlet. Today Giammatteo is characterized by two branches that converge near the province coastal road in a single channel, then flowing into the basin and to the sea (the final water supply can be regulated through a closed system of dams; Figure 4). The channel also constitutes the northern boundary of Acquatina. It is also clear that construction of the canal caused the interruption of the Acquatina water system, which was originally more extensive, including part of the areas located north of the Giammatteo river, nowadays buried. To highlight the above observations, it is possible to compare the topographic maps of Figures 3 and 5 (showing the undisturbed state of place) with that of Figure 6 (representing the situation after reclamation works). Today, the Acquatina di Frigole lagoon is bounded by man-made riverbanks mostly characterized by concrete banks and/or rock blocks for a linear extension of about $5628 \mathrm{~m}$. The trend is sub-parallel to the coastline, while the basin area covers about $424.634 \mathrm{~m}^{2}$ (Figure 2). 


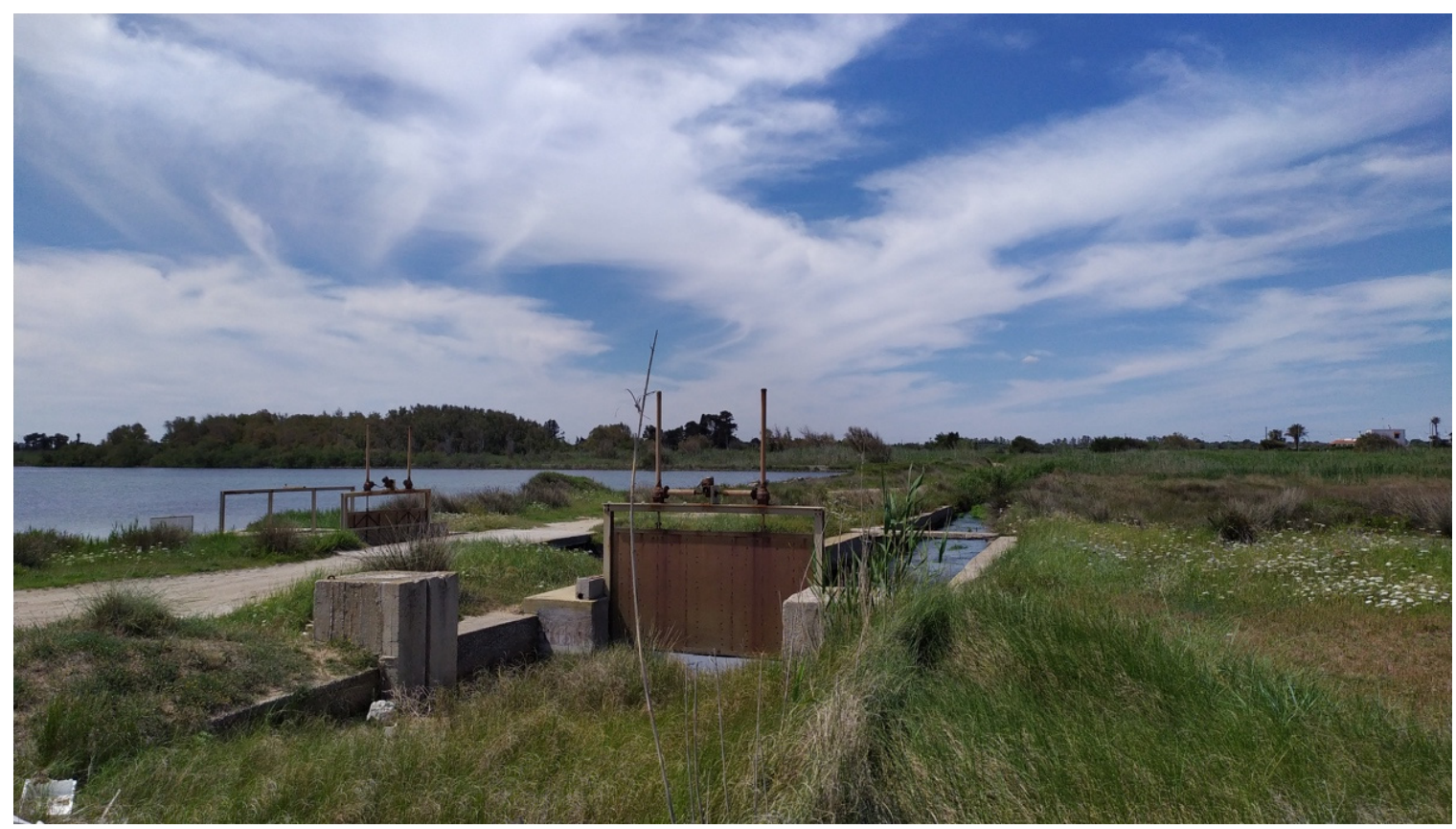

Figure 4. The water of Giammatteo Channel is canalized into the sea or in the Acquatina di Frigole lagoon through closed system of dams.

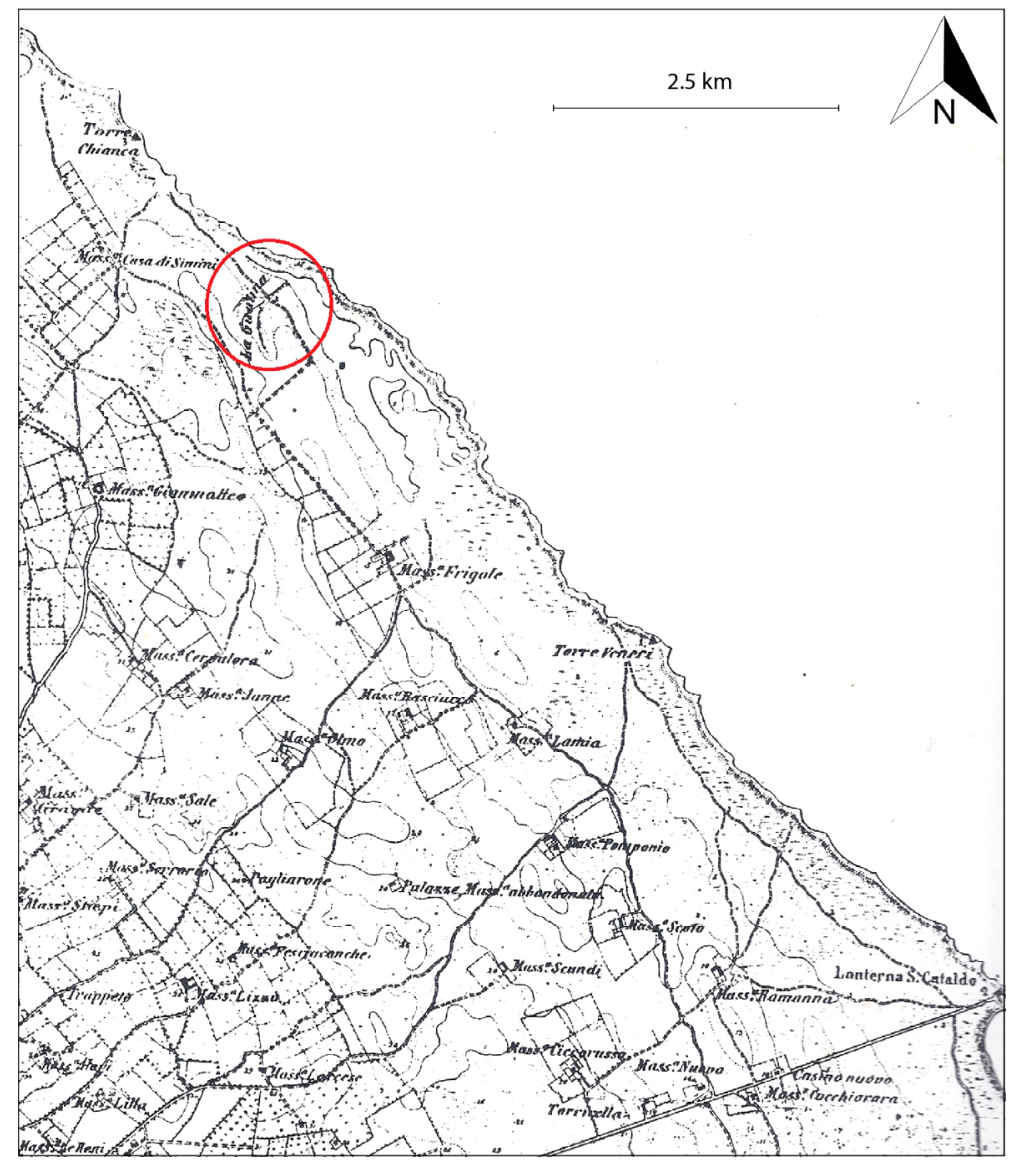

Figure 5. 1879 topographic map of the studied area: At that time, the Giammatteo Channel flowed into the Acquatina di Frigole lagoon (red circle). 


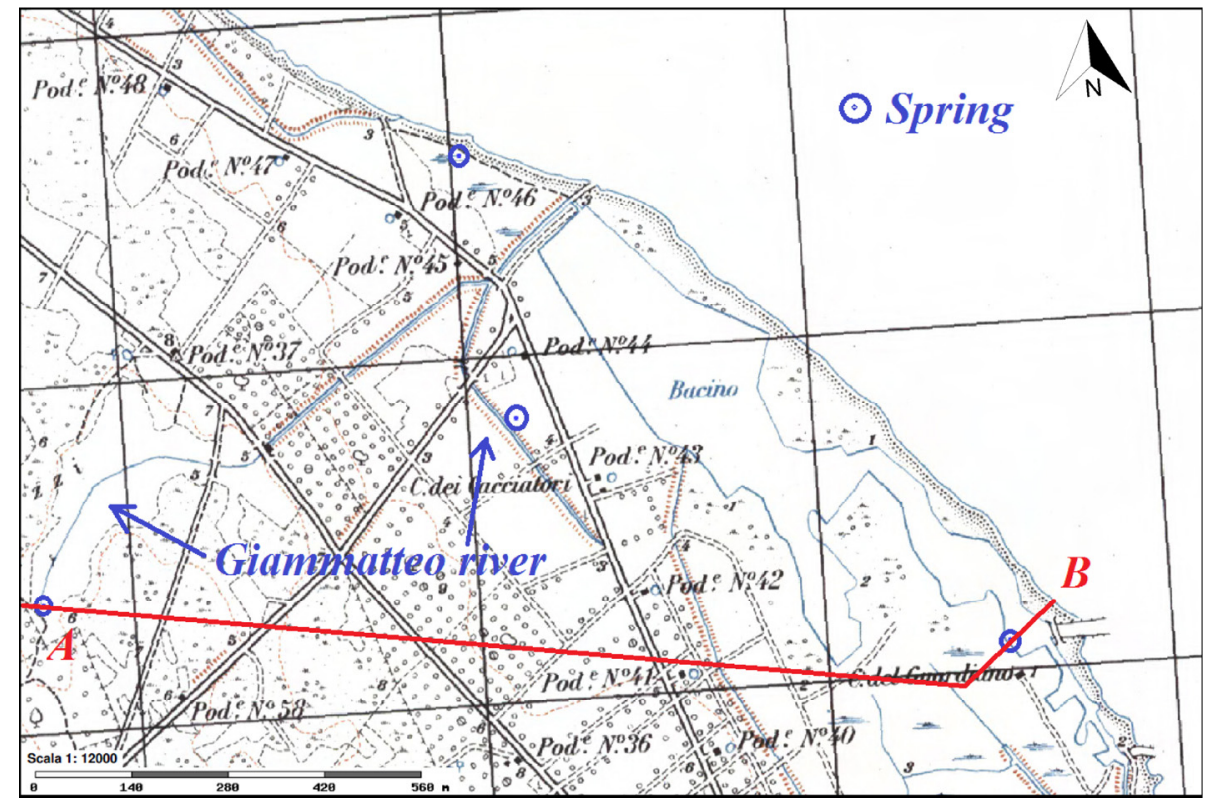

Figure 6. 1948 topographic map by Istituto Geografico Militare (Italian Geographical Army) with the localization of the springs (blue circles), showing the situation after reclamation works. The terminal part of Giammatteo River bounds to the north the Acquatina di Frigole lagoon. The red line indicates trace of the section shown in Figure 7.

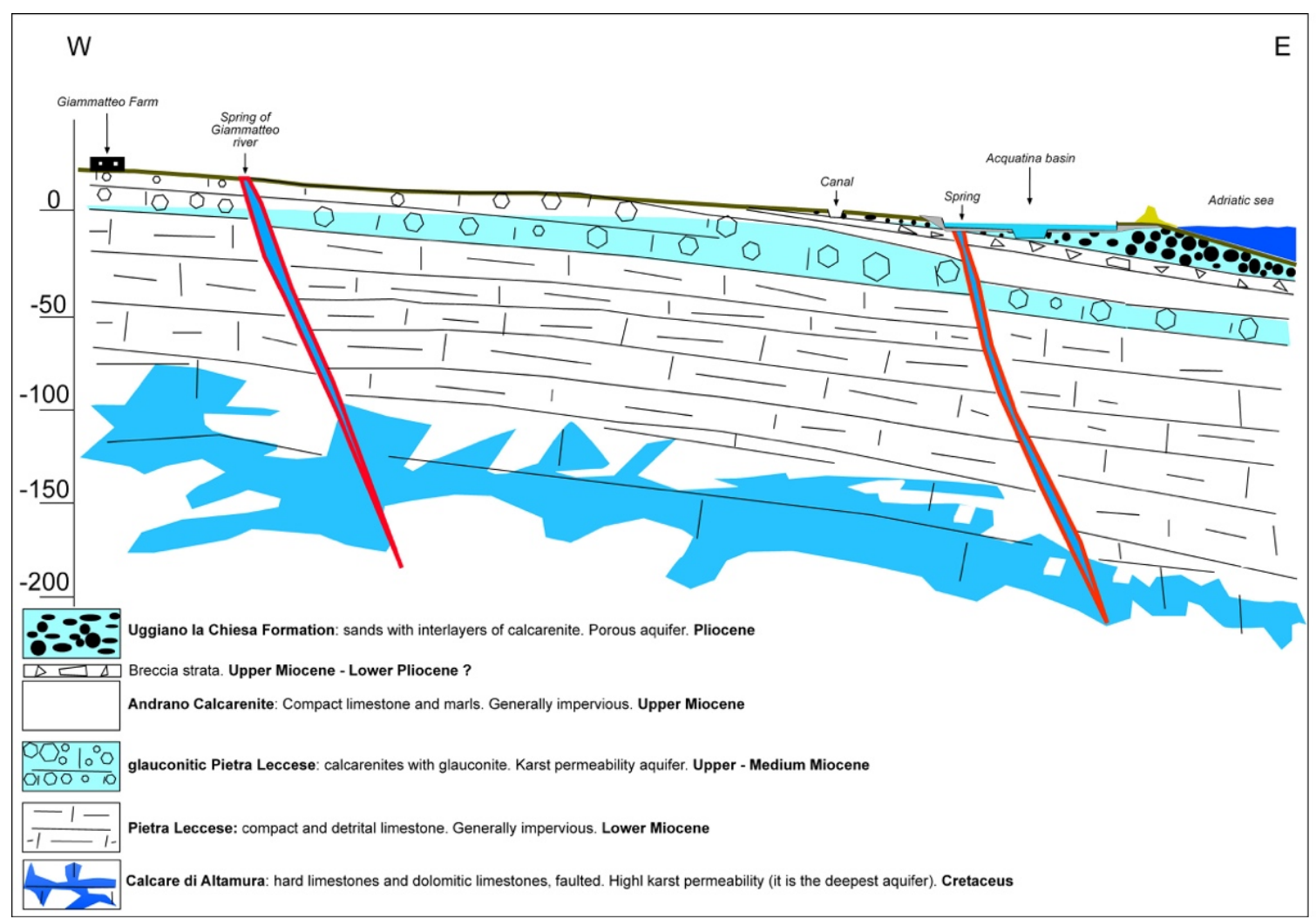

Figure 7. Schematic hydrogeological section of the studied area (not in scale). For the trace of the section see Figure 6 . Red sub-vertical lines are faults, whilst the blue colors in the section indicate the presence of groundwater.

\subsection{Hydro-Stratigraphy}

The information provided by the exploratory holes that were drilled in geological investigations conducted in the last century (1950s and 1970s), compared with the ge- 
ological surveys (Figure 8) and the lithostratigraphic attribution by Bossio et al. [114], allowing for the definition of the hydrostratigraphic framework of the area. According to Cotecchia [88], the groundwwater movement is complex, owing to presence of two separated aquifer systems: the deeper is in the Cretaceous limestones, and the other in the permeable post-Cretaceous rocks. Cretaceous rocks are intensely fractured and affected by karst phenomena, with high permeability $\left(10^{-2} \mathrm{~m} / \mathrm{s}-10^{-3} \mathrm{~m} / \mathrm{s}\right)$ [88]. The top of these rocks tends to run to depth toward the coast (from $-50 \mathrm{~m}$ to $-107 \mathrm{~m}$ below ground level; see boreholes W1/RF/F and W4RF/F in Figures 8 and 9).

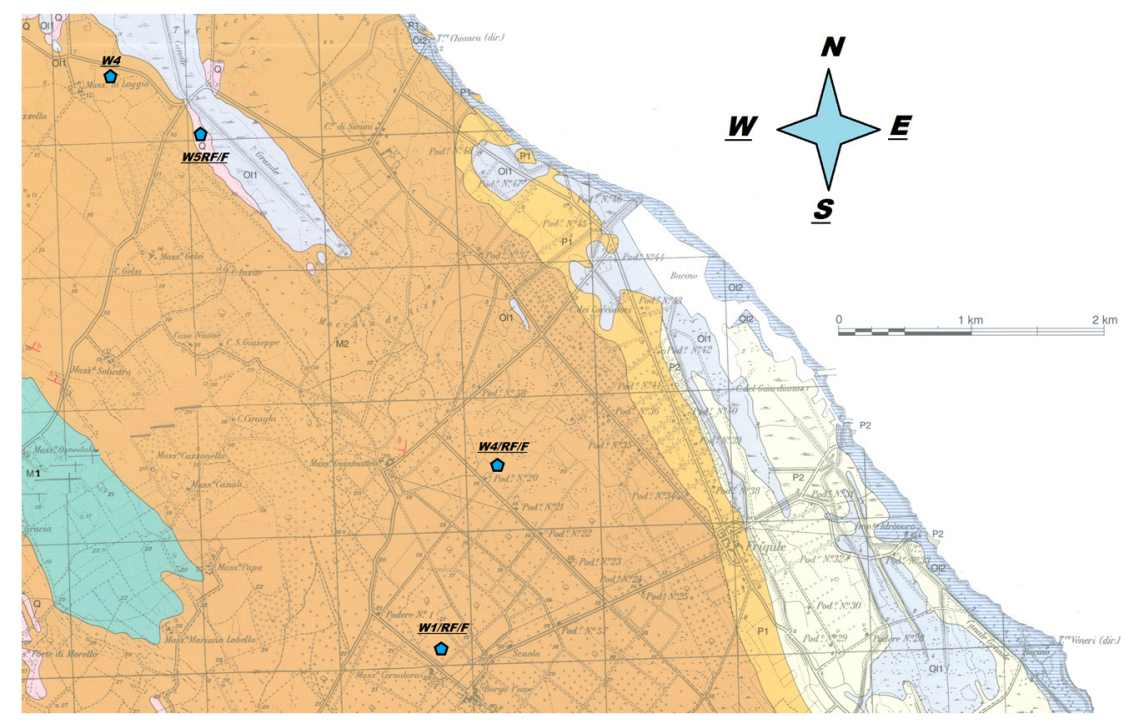

Figure 8. Geological map of the Acquatina di Frigole area (adapted from [114]). M1: Pietra Leccese (Miocene); M2: Andrano Calcarenite (Upper Miocene); P1: Leuca Breccia (Lower Pliocene); P2: Uggiano La Chiesa Formation (Pliocene); ol1: marsh deposits (recent); ol2: sands (recent). Location of the four boreholes in Figure 8 is also shown.

The Pietra Leccese Miocene sediments (M1 in Figure 8) overlay the Cretaceous rocks and crop out widely in the study area. It also includes layers of compact yellowish, finegrained calcarenites with decametric thickness [114]: these are described in the literature as "Piromafo" and are famous for the presence of glauconite, represented at the study area by greyish-greenish calcarenites with cavernous facies (Figure 9b,c). These layers host an aquifer, from some meters to $40 \mathrm{~m}$ thick, with groundwater velocities on the order of about $18 \mathrm{~m} /$ day [88]. Compact calcarenites belonging to the Upper Miocene Andrano Calcarenite formation (M2 in Figure 5) overlie the Piromafo. Eventually, the Plio-Pleistocene calcarenites and calcirudites (P1 and P2 in Figure 8) onlap the Miocene rocks, outcropping along the coast and hosting a very shallow aquifer (Figure 9d). Their low permeability is mostly due to porosity, with minor effects of karst phenomena.

The Giammatteo River originates south of the area of interest, where there are two sources from which it is fed (Figure 6). Water flowing in the river therefore circulates from the karstified Cretaceous limestone bedrock (Figure 7). Being the top of the limestone below sea level, with the less permeable Pietra Leccese Formation (fine grained calcarenites of Lower Miocene age) overlying the Cretaceous bedrock, the aquifer circulates under pressure, confined by the Miocene sediments. The presence of discontinuity systems in the Miocene succession allows the local rise of groundwater from the karst aquifer, thus originating springs $[83,90]$. In their upwelling, the waters mix with others coming from the more surficial Miocene (the aquifer hosted in the Piromafo level)-Pliocene-Pleistocene aquifers, as well as with other sources present along the river. 


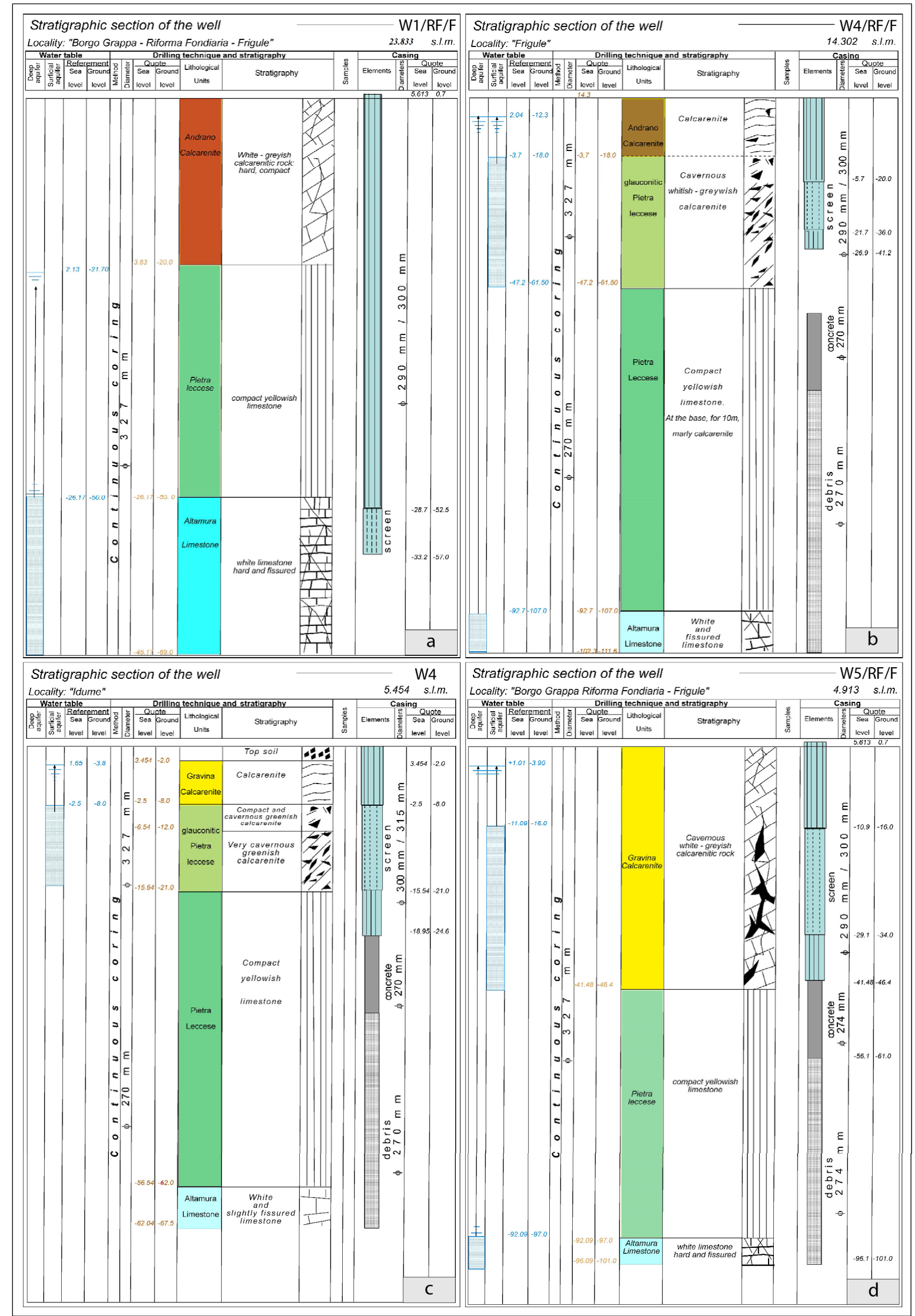

Figure 9. Stratigraphies in the Acquatina di Frigole area (data re-elaborated from the archive of Ente Irrigazione). Adapted from geological formations follows the work by Bossio et al. [114]. Borehole location is shown in Figure 8. 
The flow rate of the watercourse is about $1000 \mathrm{~L} / \mathrm{s}$, with salinity of $2.4 \mathrm{PSU}$, while salinity of the Acquatina di Frigole lagoon is about 25 PSU (Table 1). The survey of the 1879 cartography (Figure 9), at a scale of 1: 50,000, shows that once the canal only flowed into Acquatina, without any outlet to the sea (for detail see also Figure 3).

Table 1. Salinity average value (mean \pm SE) from January to December 2019 in the Acquatina di Frigole lagoon. PSU: Practical Salinity Unit.

\begin{tabular}{cc}
\hline Month & Salinity Average Value (PSU) \\
\hline January & $27.26 \pm 1.542$ \\
February & $24.61 \pm 1.774$ \\
March & $23.21 \pm 1.977$ \\
April & $29.10 \pm 1.393$ \\
May & $29.39 \pm 1.100$ \\
June & $27.84 \pm 1.500$ \\
July & $27.92 \pm 1.019$ \\
August & $30.09 \pm 1.255$ \\
September & $28.60 \pm 0.841$ \\
October & $29.09 \pm 0.967$ \\
November & $24.03 \pm 1.653$ \\
December & $33.36 \pm 1.037$ \\
\hline
\end{tabular}

The bottom is characterized by 1-m-thick clayey sediments, forcing the Pliocene aquifer to circulate under pressure. In the middle portion of the basin, where the canal is present, removal of the clayey sediments allows the outcrop of the calcarenite deposits belonging to the Pliocene Uggiano la Chiesa Formation [67]. The Pliocene unit constitute a porous aquifer in which the impermeable layer is the compact limestone of Andrano Calcarenite (Upper Miocene). Between the two units, a breccia layer is present. In conclusion, the waters of the Acquatina di Frigole lagoon derive from the spring located at its southern rim; in addition, the basin receives a further supply of seawaters at its bottom, this being at a lower elevation below the average sea level, and from the communication canals with the sea (E side) and the Giammatteo River (from inland).

\section{Results}

\subsection{Ecology}

The Acquatina di Frigole lagoon is a habitat included in a wide Site of Community Importance (SCI) and Special Area of Conservation (SAC) under the Habitat Directive 92/43/EEC, named "Aquatina di Frigole" (IT9150003) according to the NATURA 2000 network. It includes habitats with "priority" status in the Annex I of the Directive 92/43/EEC, such as $1120^{*}$ Posidonia beds (Posidonion oceanicae), 1150* Coastal lagoons and 2250* Coastal dunes with Juniperus spp. These, in danger of disappearance, have a higher degree of protection compared to 'non-priority' habitats, the latter including 1210 Annual vegetation of drift lines, 1310 Salicornia and other annuals colonizing mud and sand, 1420 Mediterranean and thermo-Atlantic halophilous scrubs (Sarcocornetea fruticosi), 2120 Shifting dunes along the shoreline with Ammophila arenaria ('white dunes') and 2260 Cisto-Lavenduletalia dune sclerophyllous scrubs.

Aquatina di Frigole has also a high variability of plant species. Along the banks of the basin, the sea aster Aster tripollum, the common reeds Phragmites communis and Phragmites australis and the glasswort Arthrocnemum glaucum are very common. The Mediterranean maquis has shrub species such as the rock rose Cistus creticus, the narrow-leaved cistus Cistus monpelliensis and tree species such as the olive tree, the maritime pine and the holm oak. Other species present are the pistache Pistacia lentiscus, the myrtle Myrtus communis, the apulian ophrys Ophrys apulica, the milkworts Polygala major, the mock privet Phillyrea latifoglia, the flax-leaved daphne Daphne gnidium and the mallow-leaved bindweed Convolvolus althaeoides. Along the dune coast, it is possible to observe the sea spurge Euphorbia paralias, the cutandia grass Cutandia maritima and the sea lily Pancratium 
maritimum, which is one of the most beautiful plants of the sandy coasts. Very resistant to arid environments and sea salt, and for this reason often used to consolidate the coastal dunes, is the sally-my-handsome Carpobrotus acinaciformis, generally living in association with the sharp cedar Juniperus oxycedrum, the cottonweed Otanthus maritimus, the hairy thorny broom Cytisus infestus and the European beachgrass Ammophila littoralis. Among the species present in Aquatina di Frigole, there is also the pillwort included among the plant species of the National Red List. In addition, the variety of environments and habitats in the entire protected area allows a rich presence of numerous nesting and migratory birds. Some of these are listed in the Annex I of Birds Directive 2009/147/CE as vulnerable and at risk of extintion, such as the purple heron Ardea purpurea, the bittern Botaurus stellaris, the hen harrier Circus cyaneus, the little bittern Ixobrychus minutus, the White-eyed Pochard Aythya nyroca and the Black-winged Stilt Himantopus himantopus. Along the embankments, it is possible to come across in many other birds, including different types of egrets and rapaceous. Furthermore, the lagoon hosts an abundant and valuable ichthyofauna, different species of crustaceans and molluscs, including the endemic Mediterranean bivalve Pinna nobilis (listed in Annex IV of the Habitats directive, and considered an endangered species in the IUCN Red list) [127-129].

\subsection{Sinkhole Evolution}

The evolution of the Acquatina sinkholes has been examined starting from 2006, the year in which the first high-resolution aerial photographs date back (Figure 10). The sinkhole process seems to have started in the central part of the basin, where the canal built for reclamation of the original marshland is present. In 2006 a high number of sinkholes was present along this channel, the highest frequency being observed exactly at the intersection with another orthogonal channel; relatively few sinkholes were recognizable in the remaining parts of the basin. Taking as a reference the northernmost portion of the basin, bounded by the two orthogonal channels and by the outer northeastern perimeter of the basin, we can observe how, in 2006, where the NE-SW channel is present, at least three sinkholes are recognizable; two of these (nos. 1 and 2 in the 2006 photo in Figure 10) are clearly outlined, with diameters of approximately $58 \mathrm{~m}$ (the sinkhole located to the east) and $56 \mathrm{~m}$, respectively. Some additional small sinkholes are present in the northern portion of the basin, showing diameters of about ten meters.

The analysis of the 2008 aerial photos shows the sinkhole process in evolution: the two features previously recognized, in 2008, reached $62 \mathrm{~m}$ in diameter, whilst additional sinkholes have opened inside the basin (zone labelled with no. 3 in the 2006 photo). The sinkholes seem to be aligned in the NW-SE direction (the same as the basin elongation), the largest reaching a diameter of $20 \mathrm{~m}$. In 2010, practically the entire portion of the canals is affected by sinking processes, which makes it difficult to discriminate among the individual sinkholes due to widespread coalescing processes. Within the basin, too, the sinkholes have grown in number (always according to the aforementioned direction) and size (the largest are about $30 \mathrm{~m}$ in diameter). The same trend can be further appreciated two years later, in the 2012 photos, with the sinkholes of less recent formation that have reached $40 \mathrm{~m}$ of diameter while some others begin to merge. In 2016 the sinkholes are widely coalescing, the diameter of the largest ones reaching $50 \mathrm{~m}$. Eventually, the 2018 photos show that almost $80 \%$ of the surface of the basin is affected by sinking processes. The survey carried out in February 2019 with the UAV DJI Phantom 4 pro, equipped with a 1-inch, 20-megapixel RGB camera, allowed us to prove that the sinkhole had reached, at that time, a diameter of $54.77 \mathrm{~m}$. The sinkhole enlargement rate can be estimated at about $5 \mathrm{~m} /$ year, with a maximum subsidence of about $0.7 \mathrm{~m}$ (Figures 11 and 12). 

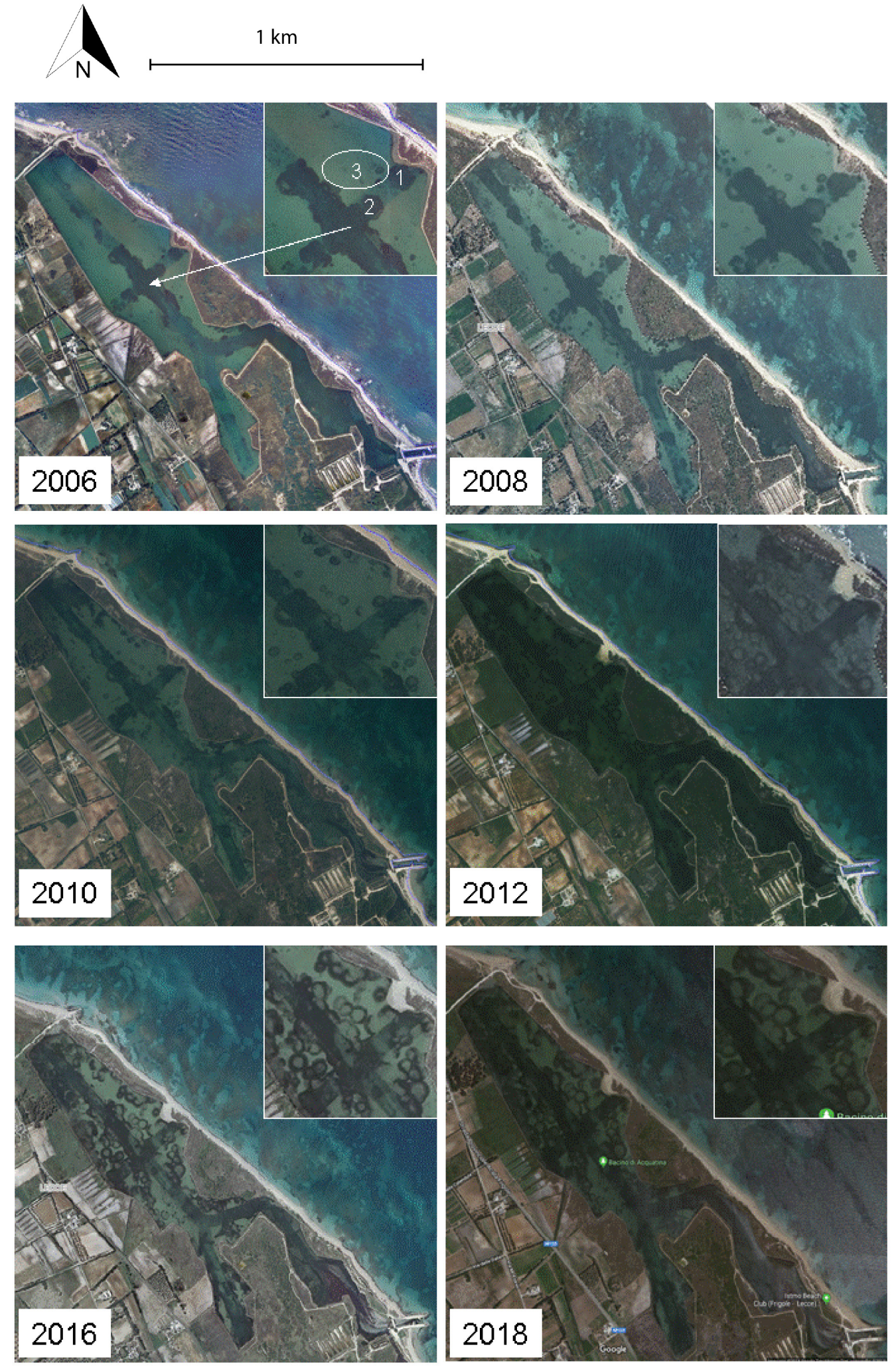

Figure 10. Sequence of aerial photographs (time span from 2006 to 2018), showing evolution of the sinkhole phenomena. 


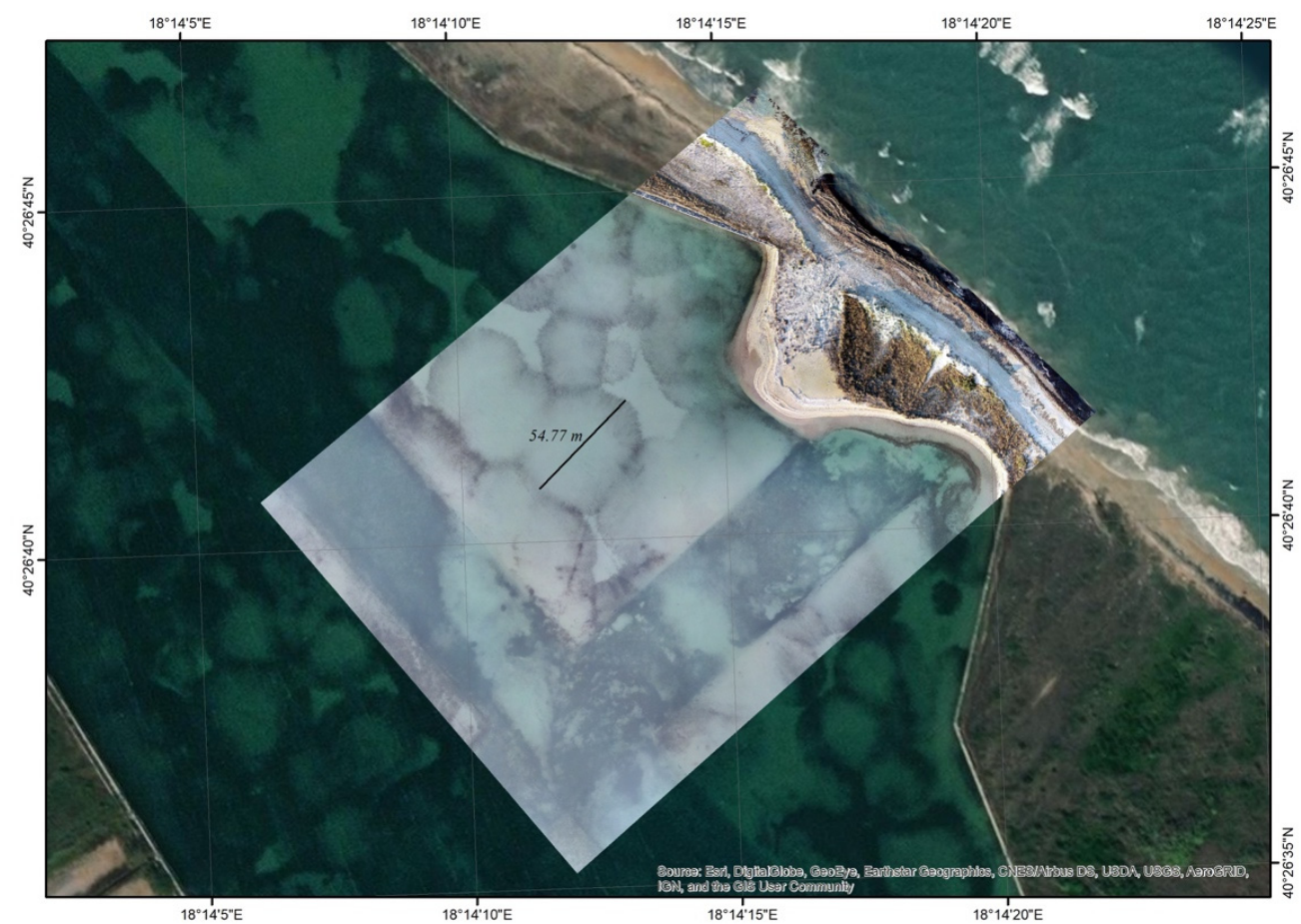

Figure 11. Detailed image of a part of Acquatina di Frigole lagoon. The image processing consisted of four steps, with Structure-from-motion (SfM) and Multi-View Stereo Reconstruction (MVS) being fundamental (step 1); this is the crucial moment for calibration and image processing (the timeconsuming step), when the geometry of the substratum is reconstructed and processed in a dense point cloud. Mesh reconstruction is step 2: starting from the dense point cloud, a continuous surface is built composed of polygons in which the vertices are the dots of the dense point cloud. Mesh colour application (step 3): basically, the mesh has no colour attribute, so the colour can be attributed as colour-per-vertex (the dense point cloud colour is transferred to the mesh polygons) or texture mapping (the images acquired during the survey are applied to the mesh polygons). 3D model (step 4): the model is scaled using at least one Ground Control Point (GCP) because the software cannot deduce the size of the objects in the pictures.

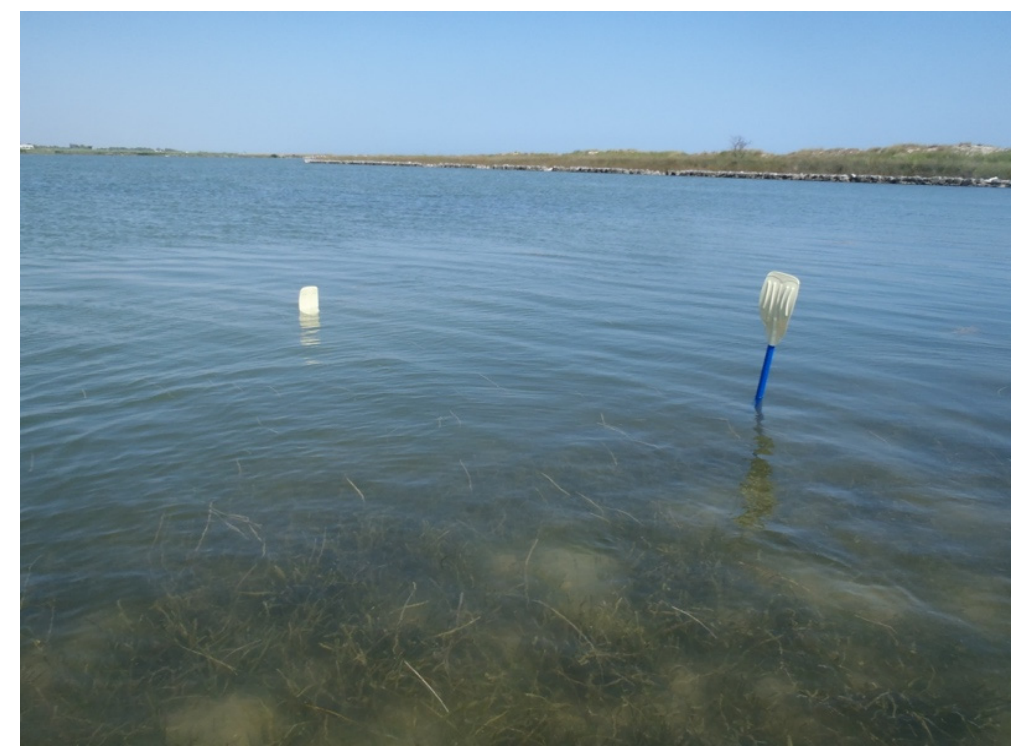

Figure 12. Detail of one of the sinkholes: the oars are located across the sinkhole rim, one outside it, and the other within the depression. The difference in elevation is about $0.7 \mathrm{~m}$. 
The substrate of the lagoon hosts the seagrass meadows Cymodocea nodosa, which appear to surround most of the sinkholes (Figure 13). This phanerogam form in the lagoon's extensive and dense meadows equivalent to those formed by others marine phanerogams. In particular, the meadows made up of this plant, even if they are not equivalent to those of Posidonia oceanica, provide an environment for the reproduction and development of even typical marine organisms. It lives either along the coasts in the hypersaline environments and in shallow water such as the lagoons [130]. The characteristics of this plant make it an excellent pioneer marine plant, capable, if conditions suitable for the survival of the plants on a seabed are restored, to colonize over time large underwater areas. The same dense seagrass meadows, mainly Cymodocea nodosa, cover the seafloor of the continental shelf of the Maltese islands in the shallower waters, reaching a maximum depth of ca. $-55 \mathrm{~m}$. The seagrass meadows colonized coarse-grained sediment and bedrock across parts of the seafloor off-shore NE Gozo, Comino to Wied Pwales and SE Malta [131]. The Maltese archipelago including Malta, Gozo and Comino is one of the few emergent areas of the Pelagian Platform consisting of thick exposures of Mesozoic shallow water carbonate sequences and volcanic deposits [131]. As observed in other areas worldwide [132-136], the vegetation colonizing specific karst landforms may provide useful information about the chemical and physical parameters of the local environment.

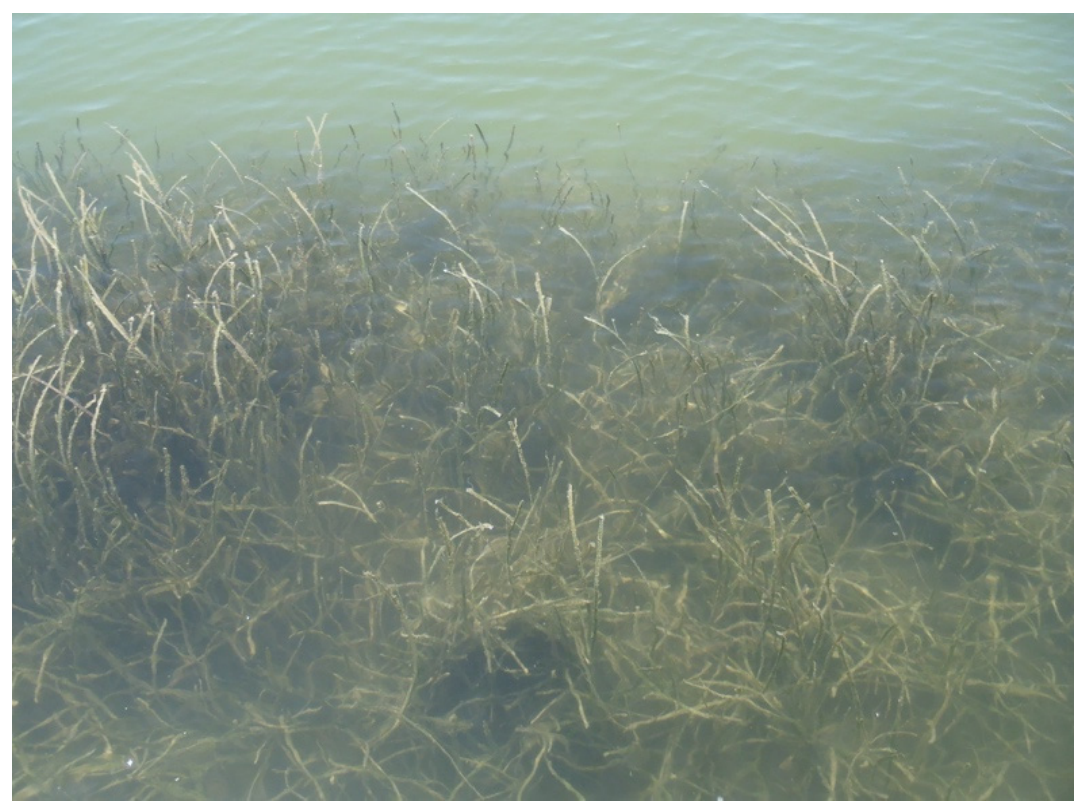

Figure 13. The seagrasses meadows with Cymodocea nodosa covering the substrate of the lagoon.

\section{Discussion}

The development of sinkholes along the main tectonic trends has been documented in many karst areas worldwide [68,137-141], thus testifying to the preminent role played by the main discontinuity systems in favouring development of karst conduits, and the consequent groundwater flow in karst aquifers along such features [142-145]. Even at the surface, without producing real sinkholes and dramatic landforms at the ground, doline occurrence is often linked to the main structural lineations in the carbonate rock mass [10,146-148]. As regards Apulian karsts, here, too, several locations have demonstrated that the alignment of the sinkhole and doline features is highly controlled by the most widespread discontinuity systems. This was true in Salento, both in the inland areas $[69,75,149]$ and at several coastlines, as in the case of Casalabate, Alliste and Torre Castiglione [37,45,46,150].

Focusing on the study area dealt with in this article, it is evident that the works for the construction of the canals at Acquatina di Frigole have weakened and thinned the layers of calcarenite rock that constituted the vault of cavities within the Mio-Pliocene sediments, generated by hyperkarst processes due to the mixing of fresh and seawaters and the 
resulting stronger aggressiveness of dissolution processes [47-49]. Upward stoping of the cavities initially caused the collapse of the vaults where these were less thick (this mostly occurred in correspondence of the canals), and where the rock mass was strongly fractured, probably also as a consequence of the excavation works. These collapses favoured the progressive enlargement of the cavities, even in the inner portions of the basin, along NW-SE oriented tectonic lines, likely associated with the axis of the synclinal fold in which the whole original Acquatina lagoon developed. Based upon the available data and the existing sets of photographs, the sinkhole enlargement rate (i.e., the increase in width of sinkholes) can be estimated at about $5 \mathrm{~m}$ per year. As concerns the typology of these karst landforms [2,3,151], the Acquatina sinkholes belong to the class of suffusion sinkholes, related to the undermining of the cover deposits by internal erosion (Figure 14). In detail, suffusion sinkholes develop where the cover behaves as a ductile or loose granular material, settling gradually without the formation of significant failure planes [2]. Typically, funnelor bowl-shaped landforms are produced, with the classical circular form in plan $[10,152]$ and a diameter in the range from less than $1 \mathrm{~m}$ to a few meters. Suffusion sinkholes differ from the other typology of features produced by the undermining of the cover deposits by internal erosion, which is cover collapse sinkhole: in this case, the cover deposits respond with brittle behaviour from a rheological standpoint, generating the upward migration of an arched cavity [1,2,153-155]. The two categories of suffusion sinkholes and cover collapse sinkholes are the most sensitive to human alterations and present the highest probability of occurrence.

In the Acquatina di Frigole case study, the loose sandy silt cover deposits moved down along the main discontinuity systems, to fill the cavities generated within the underlying Mio-Pliocene calcarenites. The contemporary upwelling of freshwater, combined with the sink in the central part of the depressions is not favourable to the establishment of Cymodocia nodosa, which, on the other hand, tends to develop and fully grow around the newly formed sinkholes. In this way, the growth and spreading of Cymodocia nodosa make the identification of the sinkhole rims much easier, marked by development of the seagrass. 


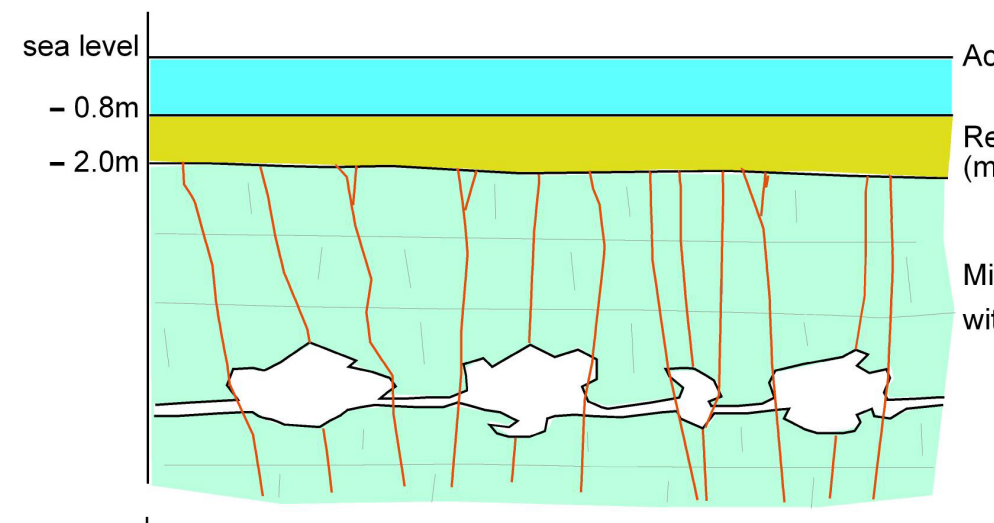

Acquatina water level

Recent non cohesive materials (mostly sands)

Miocene carbonate bedrock with fracture $(/)$ and voids

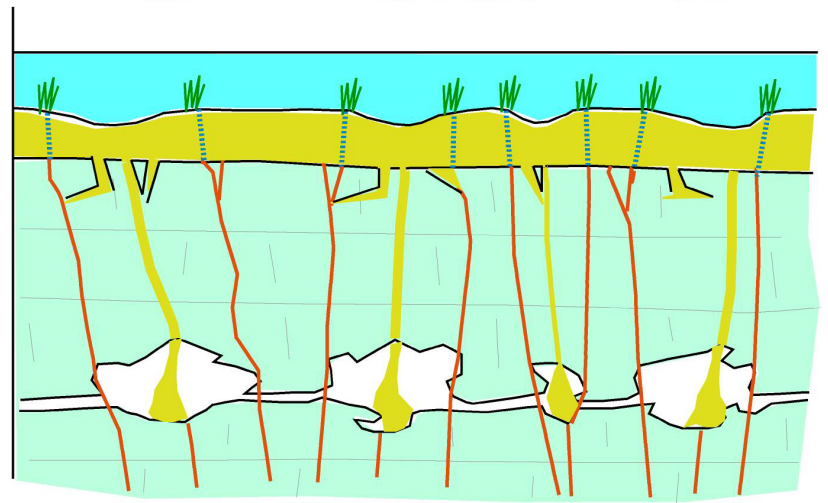

\section{Phase one}

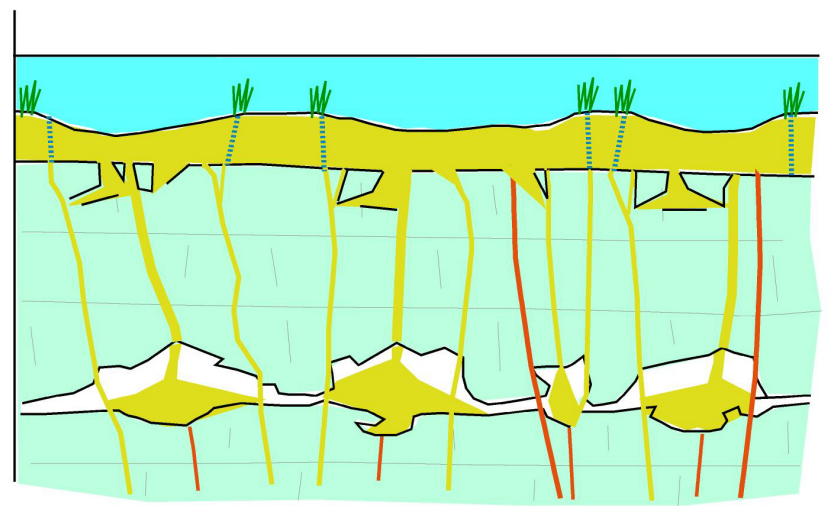

\section{Phase two}

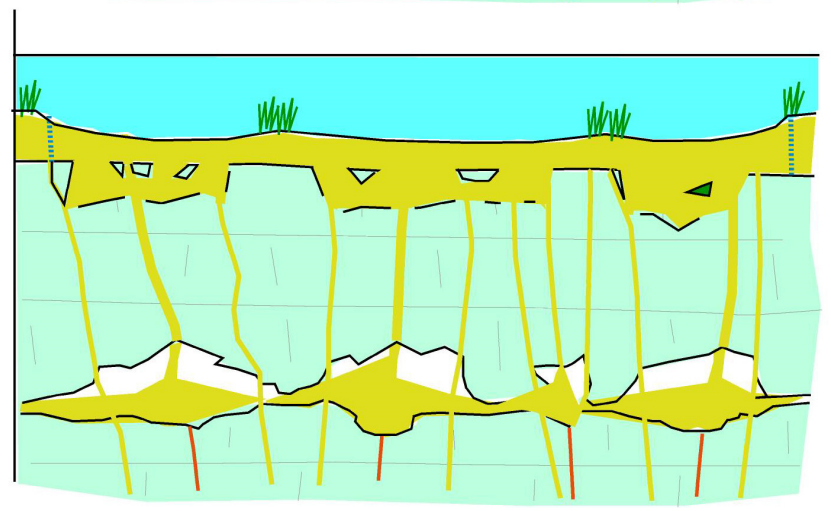

\section{Phase three}

Figure 14. Sketch of the sinkhole evolution (not to scale). Please note that the first sinkholes developed in correspondence of the two artificial canals, probably because of the reduced thickness of the recent sands. Phase one: sands move down into the voids, which are progressively enlarged by the joints, thus forming small depressions at the surface. Rising brackish water through the joints favours plants to take root; however, continuous settling of sands pushes them at the rims of the depressions. Phase two: both dissolution and sand infilling go on, and wider depressions are originated due to coalescing sinkholes. Phase three: continuing infilling determines a general lowering of the basin bottom. 


\section{Conclusions and Future Perspectives}

Sinkhole development in coastal areas has a significant impact on human activities, but, at the same time, is in some way interlinked with anthropogenic actions. Coastal areas are always zones of high economic interest due to presence of infrastructures (harbours, seafood farming, industrial activity, etc.) and to the relevance for tourist economies. Any process affecting the coast therefore represents a threaten to the local economy, with particular regard to gelogical hazards, and is worth being fully studied in order to develop the most proper actions to reduce the risk. In the case study presented here, as demonstrated by the formation and evolution of several sinkholes in a coastal marshland of southern Italy, it is highly likely that, in the near future, the Acquatina di Frigole lagoon could be further characterised by the enlargement of the documented sinkholes and/or the formation of new ones. This is clearly indicated by the high enlargement rate, showing an increase in width on the order of about $5 \mathrm{~m}$ /year, with maximum subsidence of about $0.7 \mathrm{~m}$. It is worth noting that there are not many documentations about the evolution rate of sinkholes, either in Apulia or in other karst areas worldwide (see in this regard the review in [2]). Even though many other sites affected by sinkholes are present along the Apulian coastlines, Acquatina di Frigole is of significant relevance since within the marsh area, the environment can be considered as natural after the realization of the basin and of the canals. This makes the site a wonderful laboratory to evaluate the sinkhole evolution, also in terms of their interaction with vegetable species within the marshes and with their growth in relation with the local chemical and physical conditions.

It is therefore crucial to continue monitoring the site by means of periodic surveys by drones, which could be extremely useful to detect changes in sinkhole size and to measure possible changes in the rates of formation and evolution, and ROV and subbottom profilers, useful to better define the basin bathymetry, the morphometric features of sinkholes and to recognize the top of the calcarenite bedrock below the sandy silts. Similarly, it should be relevant to integrate the presence and the evolution of the sinkholes in the Acquatina lagoon in relation to the functional processes such as the decomposition of the seagrass litter Cymodocea nodosa, as well the variation of the body size structures of the benthic macroinvertebrates in the vicinity of these structures [156-159]. The observation of these phenomena in the protected area of Acquatina di Frigole could help to predict land movement in urbanized areas and to prevent potential damage to roads and house.

Another aspect worth consideration is that of geotourism [22,23], that is, establishing pathways and organizing sites for valorisation through a naturalistic tourism aimed at favouring the conservation of the natural landscape and at allowing people to understand, from an onsite visit, the beauty of the landforms while also gaining scientifically sound information about their genesis. In Apulia, with karst as the main geomorphological agent working in the development of the local landforms, karst geosites are increasingly gaining attention, both at the surface and in the underground world as well $[21,25,30]$. Given the high tourist vocation of the region, this growing importance of karst geotourism in Apulia, as well as in Salento, planning a guided tour at Acquatina di Frigole and the surroundings coastal areas might be a good opportunity for valorisation and preservation of these marshlands, and to explain the sinkhole processes and their evolution in relation with man-made structures.

Author Contributions: Conceptualization, S.M. and M.P. (Mario Parise); methodology, S.M., M.P. (Maurizio Pinna) and M.P. (Mario Parise); UAV survey and interpretation, S.F.; ROV, F.M.D.; ecology, M.P. (Maurizio Pinna), G.M. and S.F.; hydrogeology, I.S.L.; writing—original draft preparation, review and editing, S.M., M.P. (Maurizio Pinna) and M.P. (Mario Parise); supervision, M.P. (Mario Parise). All authors have read and agreed to the published version of the manuscript.

Funding: This research was partly supported by the $e x-60 \%$ fund from the Italian Ministry of University and Research, by Funding of Basic Research Activities (FFABR) from the Italian Ministry of University and Research awarded to M. Pinna and by the ImPrEco project (Interreg ADRION Programme 2014-2020) awarded to M.P. 
Data Availability Statement: Data presented in this article are available through request to the first Author.

Acknowledgments: Authors are indebted to two anonymous reviewers for their valuable comments on the original version of the article, which certainly were useful to improve the manuscript's clarity.

Conflicts of Interest: The authors declare no conflict of interest.

\section{References}

1. Waltham, T.; Bell, F.; Culshaw, M. Sinkholes and Subsidence: Karst and Cavernous Rocks in Engineering and Construction; Springer: Berlin/Heidelberg, Germany, 2005.

2. Gutierrez, F.; Parise, M.; De Waele, J.; Jourde, H. A review on natural and human-induced geohazards and impacts in karst. Earth Sci. Rev. 2014, 138, 61-88. [CrossRef]

3. Parise, M. Sinkholes. In Encyclopedia of Caves, 3rd ed.; White, W.B., Culver, D.C., Pipan, T., Eds.; Academic Press: Cambridge, MA, USA; Elsevier: Amsterdam, The Netherlands, 2019; pp. 934-942.

4. Parise, M. A present risk from past activities: Sinkhole occurrence above underground quarries. Carbonates Evaporites 2012, 27, 109-118. [CrossRef]

5. Gil, H.; Pepe, M.; Soriano, M.A.; Parise, M.; Pocovì, A.; Luzon, A.; Perez, A.; Basso, A. Sviluppo ed evoluzione di sprofondamenti in rocce solubili: Un confronto tra il carso coperto del Bacino dell'Ebro (Spagna) e la Penisola Salentina (Italia). Mem. Descr. Della Carta Geol. D'italia 2013, 93, 253-276.

6. Margiotta, S.; Negri, S.; Parise, M.; Quarta, T. Karst geosites at risk of collapse: The sinkholes at Nociglia (Apulia, SE Italy). Environ. Earth Sci. 2016, 75, 8. [CrossRef]

7. Advances in Karst Research: Theory, Fieldwork and Applications; Parise, M.; Gabrovsek, F.; Kaufmann, G.; Ravbar, N. (Eds.) Special Publication, 466; Geological Society: London, UK, 2018.

8. Zumpano, V.; Pisano, L.; Parise, M. An integrated framework to identify and analyze karst sinkholes. Geomorphology 2019, 332, 213-225. [CrossRef]

9. Ford, D.C.; Williams, P. Karst Hydrogeology and Geomorphology; Wiley: Chichester, UK, 2007.

10. Sauro, U. Dolines and sinkholes: Aspects of evolution and problems of classification. Acta Carsologica 2003, 32, 41-52. [CrossRef]

11. De Waele, J.; Gutiérrez, F.; Parise, M.; Plan, L. Geomorphology and natural hazards in karst areas: A review. Geomorphology 2007, 134, 1-8. [CrossRef]

12. Natural and Anthropogenic Hazards in Karst Areas: Recognition, Analysis and Mitigation; Parise, M.; Plan, L. (Eds.) Special Publication, 279; Geological Society: London, UK, 2007.

13. Gutiérrez-Santolalla, F.; Gutiérrez-Elorza, M.; Marín, C.; Desir, G.; Maldonado, C. Spatial distribution, morphometry and activity of La Puebla de Alfindén sinkhole field in the Ebro river valley (NE Spain): Applied aspects for hazard zonation. Environ. Geol. 2005, 48, 360-369. [CrossRef]

14. Farrant, A.; Cooper, A. Karst geohazards in the UK: The use of digital data for hazard management. Q. J. Eng. Geol. Hydrogeol. 2008, 41, 339-356. [CrossRef]

15. Heidari, M.; Khanlari, G.R.; Taleb Beydokhti, A.R.; Momeni, A.A. The formation of cover collapse sinkholes in North of Hamedan, Iran. Geomorphology 2011, 132, 76-86. [CrossRef]

16. Zhou, W.; Beck, B.F. Engineering issues in karst. In Karst Management; Van Beynen, P., Ed.; Springer: Berlin/Heidelberg, Germany, 2011; pp. 9-45.

17. Galve, J.P.; Castañeda, C.; Gutiérrez, F. Railway deformation detected by DInSAR over active sinkholes in the Ebro Valley evaporite karst, Spain. Nat. Hazards Earth Syst. Sci. 2015, 15, 2439-2448. [CrossRef]

18. Zini, L.; Calligaris, C.; Forte, E.; Petronio, L.; Zavagno, E.; Boccali, C.; Cucchi, F. A multidisciplinary approach in sinkhole analysis: The Quinis village case study (NE-Italy). Eng. Geol. 2015, 197, 132-144. [CrossRef]

19. Lei, M.; Gao, Y.; Jiang, X.; Guan, Z. Mechanism analysis of sinkhole formation at Maohe village, Liuzhou city, Guangxi province, China. Environ. Earth Sci. 2016, 75, 542. [CrossRef]

20. Szúcs, E.; Gönczy, S.; Bozsó, I.; Bányai, L.; Szakacs, A.; Szárnya, C.; Wesztergom, V. Evolution of surface deformation related to salt-extraction-caused sinkholes in Solotvyno (Ukraine) revealed by Sentinel-1 radar interferometry. Nat. Hazards Earth Syst. Sci. 2021, 21, 977-993. [CrossRef]

21. Mastronuzzi, G.; Valletta, S.; Damiani, A.; Fiore, A.; Francescangeli, R.; Giandonato, P.B.; Iurilli, V.; Sabato, L. Geositi della Puglia; Graphic Concept Lab: Bari, Italy, 2015; p. 394.

22. Hose, T.A. Geo-tourism-Appreciating the deep side of landscapes. In Niche Tourism: Contemporary Issues, Trends and Cases; Novelli, M., Ed.; Elsevier: New York, NY, USA, 2005; pp. 27-37.

23. Dowling, R.K.; Newsome, D. Geotourism; Elsevier: Oxford, UK, 2006.

24. Newsome, D.; Dowling, R.K. Geotourism: The Tourism of Geology and Landscape; Goodfellow Publishers: Oxford, UK, 2010.

25. Sansò, P.; Margiotta, S.; Mastronuzzi, G.; Vitale, A. The geological heritage of Salento Leccese (Apulia, southern Italy). Geoheritage 2015, 7, 85-101. [CrossRef]

26. Margiotta, S.; Sansò, P. Otranto Leuca coast Geopark (Salento, Italy): A proposal for the institution. Geoheritage 2014, 6, 305-316. [CrossRef] 
27. Margiotta, S.; Sansò, P. Abandoned Quarries and Geotourism: An Opportunity for the Salento Quarry District (Apulia, Southern Italy). Geoheritage 2017, 9, 463-477.

28. Fidelibus, M.D.; Pellicani, R.; Argentiero, I.; Spilotro, G. The Geoheritage of the Water Intake of Triglio Ancient Aqueduct (Apulia Region, Southern Italy): A Lesson of Advanced Technology Insensitive to Climate Changes from an Ancient Geosite. Geoheritage 2018, 10, 327-339. [CrossRef]

29. Margiotta, S.; Parise, M. Hydraulic and Geomorphological Hazards at Wetland Geosites Along the Eastern Coast of Salento (SE Italy). Geoheritage 2019, 11, 1655-1666. [CrossRef]

30. Liso, I.S.; Chieco, M.; Fiore, A.; Pisano, L.; Parise, M. Underground geosites and caving speleotourism: Some considerations, from a case study in Southern Italy. Geoheritage 2020, 12, 13. [CrossRef]

31. Parise, M.; Lollino, P. A preliminary analysis of failure mechanisms in karst and man-made underground caves in Southern Italy. Geomorphology 2011, 134, 132-143. [CrossRef]

32. Parise, M. A procedure for evaluating the susceptibility to natural and anthropogenic sinkholes. Georisk 2015, 9, 272-285. [CrossRef]

33. Fiore, A.; Parise, M. Cronologia degli eventi di sprofondamento in Puglia, con particolare riferimento alle interazioni con l'ambiente antropizzato. Mem. Descr. Della Carta Geol. D'italia 2013, 93, 239-252.

34. Parise, M.; Vennari, C. A chronological catalogue of sinkholes in Italy: The first step toward a real evaluation of the sinkhole hazard. In Proceedings of the 13th Multidisciplinary Conference on Sinkholes and the Engineering and Environmental Impacts of Karst, Carlsbad, NM, USA, 6-10 May 2013; pp. 383-392.

35. Parise, M.; Vennari, C. Distribution and features of natural and anthropogenic sinkholes in Apulia. In EuroKarst 2016, Neuchatel. Advances in the Hydrogeology of Karst and Carbonate Reservoirs; Renard, P., Bertrand, C., Eds.; Springer: Berlin/Heidelberg, Germany, 2017; pp. 27-34.

36. Taviani, M.; Angeletti, L.; Campiani, E.; Ceregato, A.; Foglini, F.; Maseli, V.; Morsilli, M.; Parise, M.; Trincardi, F. Drowned karst landscape offshore the Apulian Margin (Southern Adriatic Sea, Italy). J. Cave Karst Stud. 2012, 74, 197-212. [CrossRef]

37. Margiotta, S.; Negri, S.; Parise, M.; Valloni, R. Mapping the susceptibility to sinkholes in coastal areas, based on stratigraphy, geomorphology and geophysics. Nat. Hazards 2012, 62, 657-676. [CrossRef]

38. Norris, R.M.; Back, W. Erosion of seacliffs by groundwater. In Groundwater Geomorphology: The Role of Subsurface Water in Earth-Surface Processes and Landforms; Higgins, C.G., Coates, D.R., Eds.; Special Paper 252; Geological Society of America: Boulder, CO, USA, 1990; pp. 283-290.

39. White, W.B. Surface and near-surface karst landforms. In Groundwater Geomorphology: The Role of Subsurface Water in Earth-Surface Processes and Landforms; Higgins, C.G., Coates, D.R., Eds.; Special Paper 252; Geological Society of America: Boulder, CO, USA, 1990; pp. 157-175.

40. Forth, R.A.; Butcher, D.; Senior, R. Hazard mapping of karst along the coast of the Algarve, Portugal. Eng. Geol. 1999, 52, 67-74. [CrossRef]

41. Closson, D.; Karaki, N.A.; Klinger, Y.; Hussein, M.J. Subsidence and sinkhole hazards assessment in the southern Dead Sea area, Jordan. Pure Appl. Geophys. 2005, 162, 221-248. [CrossRef]

42. Closson, D.; Karaki, N.A.; Milisavljevic, N.; Hallot, F.; Acheroy, M. Salt-dissolution induced subsidence in the Dead Sea area detected by applying interferometric techniques to ALOS Palsar Synthetic Aperture Radar images. Geodin. Acta 2010, $23,65-78$. [CrossRef]

43. Ezersky, M.; Legchenko, A.; Camerlynck, C.; Al-Zoubi, A. Identification of sinkhole development mechanism based on a combined geophysical study in Nahal Hever South area (Dead Sea coast of Israel). Environ. Geol. 2009, 58, 1123-1141. [CrossRef]

44. Frumkin, A.; Ezersky, M.; Al-Zoubi, A.; Akkawi, E.; Abueladas, A.R. The Dead Sea sinkhole hazard: Geophysical assessment of salt dissolution and collapse. Geomorphology 2011, 134, 1102-1117. [CrossRef]

45. Bruno, E.; Calcaterra, D.; Parise, M. Development and morphometry of sinkholes in coastal plains of Apulia, southern Italy. Preliminary sinkhole susceptibility assessment. Eng. Geol. 2008, 99, 198-209.

46. Basso, A.; Bruno, E.; Parise, M.; Pepe, M. Morphometric analysis of sinkholes in a karst coastal area of southern Apulia (Italy). Environ. Earth Sci. 2013, 70, 2545-2559. [CrossRef]

47. Bogli, A. Mischungkorrosion-Ein Beitrag zum Verstärkungsproblem. Erdkunde 1964, 18, 83-92. [CrossRef]

48. Cigna, A.A.; Forti, P. The speleogenetic role of the air flow caused by convection. Int. J. Speleol. 1986, 15, 41-52. [CrossRef]

49. Dreybrodt, W. Processes in Karst Systems: Physics, Chemistry, and Geology; Springer: Berlin/Heidelberg, Germany, 1988.

50. Lace, M.J.; Mylroie, J.E. Coastal Karst Landforms; Springer: Berlin/Heidelberg, Germany, 2013.

51. Trudgill, S.T. The marine erosion of limestones on Aldabra Atoll, Indian Ocean. Z. Fur Geomorphol. 1976, 26, 164-200.

52. Day, M. Doline morphology and development in Barbados. Ann. Assoc. Am. Geogr. 1983, 73, 206-219. [CrossRef]

53. Back, W.; Hanshaw, B.B.; Herman, J.S.; Van Driel, J.N. Differential dissolution of a Pleistocene reef in the ground-water mixing zone of coastal Yucatan, Mexico. Geology 1986, 14, 137-140. [CrossRef]

54. Baceta, J.I.; Wright, V.P.; Pujalte, V. Palaeo-mixing zone karst features from Palaeocene carbonates of north Spain: Criteria for recognizing a potentially widespread but rarely documented diagenetic system. Sediment. Geol. 2001, 139, 205-216. [CrossRef]

55. Palmer, A.N. Cave Geology; Cave Books: Dayton, OH, USA, 2007.

56. Karst Rock Features—Karren Sculpturing; Gines, A.; Knez, M.; Slabe, T.; Dreybrodt, W. (Eds.) Carstologia 9; Zalozba ZRC/ZRC Publishing: Ljubljana, Slovenia, 2009. 
57. Beccarisi, L.; Ernandes, P.; Delle Rose, M.; Zuccarello, V. Valutazione dello stato di conservazione delle "spunnulate" della costa di Porto Cesareo e Nardò (provincia di Lecce) con un approccio vegetazionale. Thalass. Salentina 2006, 29, 215-236.

58. Denitto, F.; Moscatello, S.; Palmisano, P.; Poto, M.; Onorato, R. Novità speleologiche, idrologiche e naturalistiche dalla Palude del Capitano (pSIC IT9150013), Costa Neretina (Lecce). Thalass. Salentina 2006, 29, 99-116.

59. Onorato, R.; Belmonte, G.; Costantini, A. Le grotte sommerse della costa neretina (Salento, SE Italia). Thalass. Salentina 2006, 29, 39-54.

60. Onorato, M.; Onorato, R.; Posi, M.E.; Poto, M. La Spunnulata della Pajara. Esplorazione e prime osservazioni. Thalass. Salentina 2017, $39,73-82$.

61. Belmonte, G.; Costantini, A.; Sorrentino, F.; Licchelli, C.; Poto, M.; Onorato, R. Le grotte sommerse dell'Area Marina Protetta "Porto Cesareo". Thalass. Salentina 2011, 33, 15-38.

62. Parise, M.; Palmisano, P.; Onorato, R. Contributo alla conoscenza dei fenomeni carsici di collasso in zone costiere del Salento Jonico (Puglia): La Spunnulata della Pajara. Thalass. Salentina 2017, 39, 99-122.

63. Delle Rose, M.; Parise, M. Karst subsidence in south-central Apulia Italy. Int. J. Speleol. 2002, 31, 181-199. [CrossRef]

64. Delle Rose, M.; Federico, A.; Parise, M. Sinkhole genesis and evolution in Apulia, and their interrelations with the anthropogenic environment. Nat. Hazards Earth Sys. Sci. 2004, 4, 747-755. [CrossRef]

65. Parise, M. I sinkholes in Puglia. Mem. Descr. Della Carta Geol. D'italia 2008, 85, 309-334.

66. Parise, M. Surface and sub-surface karst geomorphology in the Murge (Apulia, southern Italy). Acta Carsologica 2011, 40, 79-93. [CrossRef]

67. Del Prete, S.; Di Crescenzo, G.; Santangelo, N.; Santo, A. Collapse sinkholes in Campania (southern Italy): Predisposing factors, genetic hypothesis and susceptibility. Z. Geomorph. 2010, 54, 259-284. [CrossRef]

68. Del Prete, S.; Iovine, G.; Parise, M.; Santo, A. Origin and distribution of different types of sinkholes in the plain areas of Southern Italy. Geodin. Acta 2010, 23, 113-127. [CrossRef]

69. Festa, V.; Fiore, A.; Parise, M.; Siniscalchi, A. Sinkhole evolution in the Apulian karst of southern Italy: A case study, with some considerations on sinkhole hazards. J. Cave Karst Stud. 2012, 74, 137-147. [CrossRef]

70. Martinotti, M.E.; Pisano, L.; Marchesini, I.; Rossi, M.; Peruccacci, S.; Brunetti, M.T.; Melillo, M.; Amoruso, G.; Loiacono, P.; Vennari, C.; et al. Landslides, floods and sinkholes in a karst environment: The 1-6 September 2014 Gargano event, southern Italy. Nat. Hazards Earth Syst. Sci. 2017, 17, 467-480. [CrossRef]

71. Calcaterra, D.; Parise, M. The contribution of historical information in the assessment of the landslide hazard. In The Use of Historical Data in Natural Hazard Assessments; Glade, T., Albini, P., Frances, F., Eds.; Advances in Natural and Technological Hazards Research, 17; Kluwer Academic Publishers: Amsterdam, The Netherlands, 2001; pp. 201-217.

72. The Use of Historical Data in Natural Hazard Assessments; Glade, T.; Albini, P.; Frances, F. (Eds.) Advances in Natural and Technological Hazards Research, 17; Kluwer Academic Publishers: Amsterdam, The Netherlands, 2001.

73. Parise, M.; Federico, A.; Delle Rose, M.; Sammarco, M. Karst terminology in Apulia (Southern Italy). Acta Carsologica 2003, 32, 65-82. [CrossRef]

74. Delle Rose, M.; Parise, M. Water management in the karst of Apulia, southern Italy. In Sustainability of the Karst Environment. Dinaric Karst and Other Karst Regions, Proceedings of the International Interdisciplinary Scientific Conference, India, 2-4 December 2010; Bonacci, O., Ed.; Series on Groundwater no. 2; IHP-UNESCO: Paris, France, 2010; pp. 33-40.

75. Pepe, M.; Parise, M. Structural control on development of karst landscape in the Salento Peninsula (Apulia, SE Italy). Acta Carsologica 2014, 43, 101-114. [CrossRef]

76. Ciaranfi, N.; Pieri, P.; Ricchetti, G. Note alla Carta Geologica delle Murge e del Salento (Puglia centro-meridionale). Mem. Della Soc. Geol. Ital. 1988, 41, 449-460.

77. Tozzi, M.; Kissel, C.; Funiciello, R.; Laj, C.; Parotto, M. A clockwise rotation of southern Apulia? Geophys. Res. Lett. 1988, 15, 681-684. [CrossRef]

78. Ricchetti, G.; Ciaranfi, N.; Luperto Sinni, E.; Mongelli, F.; Pieri, P. Geodinamica ed evoluzione sedimentaria e tettonica dell'Avampaese Apulo. Mem. Della Soc. Geol. Ital. 1988, 41, 57-82.

79. Doglioni, C.; Mongelli, F.; Pieri, P. The Puglia uplift (SE Italy): An anomaly in the foreland of the Apenninic subduction due to buckling of a thick continental lithosphere. Tectonics 1994, 13, 1309-1321. [CrossRef]

80. Pieri, P.; Festa, V.; Moretti, M.; Tropeano, M. Quaternary tectonic of the Murge area (Apulian foreland-Southern Italy). Ann. Di Geofis. 1997, 40, 1395-1404.

81. Margiotta, S.; Negri, S. Geophysical and stratigraphical research into deep groundwater and intruding seawater in the Mediterranean area (the Salento peninsula, Italy). Nat. Hazards Earth Syst. Sci. 2005, 5, 127-136. [CrossRef]

82. Giudici, M.; Margiotta, S.; Mazzone, F.; Negri, S.; Vassena, C. Modelling hydrostratigraphy and groundwater flow of a fractured and karst aquifer in a Mediterranean basin (Salento peninsula, southeastern Italy). Environ. Earth Sci. 2012, 67, $1891-1907$. [CrossRef]

83. Cotecchia, V. Le acque sotterranee e l'intrusione marina in Puglia: Dalla ricerca all'emergenza nella salvaguardia della risorsa. Mem. Descr. Carta Geol. D'italia 2014, 92, 1-416.

84. Masciopinto, C.; Liso, I.S.; Caputo, M.C.; De Carlo, L. An integrated approach based on numerical modelling and geophysical survey to map groundwater salinity in fractured coastal aquifers. Water 2017, 9, 875. [CrossRef] 
85. Cotecchia, V. Sulle caratteristiche delle sorgenti e sulle modalità di rinvenimento della falda profonda nella Penisola Salentina in rapporto alla struttura dei calcari cretacici della regione. Ann. Della Fac. Di Ing. 1956, 2, 88-101.

86. Cotecchia, V. Sviluppi della teoria di Ghyben ed Herzberg nello studio idrogeologico dell'alimentazione e dell'impiego delle falde acquifere, con riferimento a quella profonda delle Murge e del Salento. Geotecnica 1958, 6, 301-318.

87. Orabona, E.; Cotecchia, V. La stratificazione salina nella falde con superfici di fondo rappresentate dall'acqua di marina e precisazioni sul comportamento idraulico dei pozzi relativi a siffatte falde. Ing. Sanit. 1959, 1, 1-15.

88. Cotecchia, V. Studi e ricerche sulle acque sotterranee e sull'intrusione marina in Puglia (Penisola Salentina). Quad. Ist. Ric. Acque 1977, 20, 25-29.

89. Cotecchia, V.; Tadolini, T.; Tulipano, L. Sea water intrusion in the planning of groundwater resources protection and utilization in the Apulia region (Southern Italy). Geol. Appl. Idrogeol. 1983, 18, 367-382.

90. Liso, I.S.; Parise, M. Apulian karst springs: A review. J. Environ. Sci. Eng. Technol. 2020, 8, 63-83.

91. Cotecchia, V.; Scuro, M.; Mezzina, G. Depletetion of the Cretacic Carbonate aquifer in Salento peninsula (Southeastern Italy): The case of Chidro Spring. Eng. Geol. Soc. Terit. 2015, 2, 105-109.

92. Portoghese, I.; Masciale, R.; Caputo, M.C.; De Carlo, L.; Malcangio, D. Combined Discharge and Thermo-Salinity Measurements for the Characterization of a Karst Spring System in Southern Italy. Sustainability 2020, 12, 3311. [CrossRef]

93. Margiotta, S. Idume e Altre Storie D'acqua; Primiceri Editore: Padova, Italy, 2020.

94. D'Angeli, I.M.; Vattano, M.; Parise, M.; De Waele, J. The coastal sulfuric acid cave system of Santa Cesarea Terme (Southern Italy). In Hypogene Karst Regions and Caves of the World; Klimchouk, A., Palmer, A.N., De Waele, J., Auler, A.S., Audra, P., Eds.; Cave and Karst Systems of the World; Springer: Berlin/Heidelberg, Germany, 2017; pp. 161-168.

95. D'Angeli, I.M.; Parise, M.; Vattano, M.; Madonia, G.; Galdenzi, S.; De Waele, J. Sulfuric acid caves of Italy: A review. Geomorphology 2019, 333, 105-122. [CrossRef]

96. D'Angeli, I.M.; De Waele, J.; Fiorucci, A.; Vigna, B.; Bernasconi, S.M.; Florea, L.J.; Liso, I.S.; Parise, M. Hydrogeology and geochemistry of the sulfur karst springs at Santa Cesarea Terme (Apulia, southern Italy). Hydrogeol. J. 2021, 29, 481-498. [CrossRef]

97. Alfio, M.R.; Balacco, G.; Parisi, A.; Totaro, V.; Fidelibus, M.D. Drought Index as Indicator of Salinization of the Salento Aquifer (Southern Italy). Water 2020, 12, 1927. [CrossRef]

98. De Filippis, G.; Foglia, L.; Giudici, M.; Mehl, S.; Margiotta, S.; Negri, S. Seawater intrusion in karstic, coastal aquifers: Current challenges and future scenarios in the Taranto area (southern Italy). Sci. Total Environ. 2016, 573, 1340-1351. [CrossRef] [PubMed]

99. De Filippis, G.; Foglia, L.; Giudici, M.; Mehl, S.; Margiotta, S.; Negri, S. Effects of different boundary conditions on the simulation of groundwater flow in a multi-layered coastal aquifer system (Taranto Gulf, southern Italy). Hydrogeol. J. 2017, 25, $2123-2138$. [CrossRef]

100. De Filippis, G.; Margiotta, S.; Caruso, F.; Negri, S.L. Open questions about the hydrodynamic behaviour deep coastal aquifer of the Salento peninsula (south eastern Italy): Coupling knowledge expert data and numerical modelling for testing hydrogeological conceptuals models. Sci. Total Environ. 2020, 715, 136962. [CrossRef]

101. Fidelibus, M.; Calò, G.; Tinelli, R.; Tulipano, L. Salt ground waters in the Salento karstic coastal aquifer (Apulia, Southern Italy). In Advances in the Research of Aquatic Environment; Lambrakis, N., Stournaras, G., Katsanou, K., Eds.; Environmental Earth Science Series; Springer: Berlin/Heidelberg, Germany, 2011; Volume 1, pp. 407-415. [CrossRef]

102. Polemio, M.; Dragone, V.; Limoni, P.P. Monitoring and methods to analyse the groundwater quality degradation risk in coastal karstic aquifers (Apulia, southern Italy). Environ. Geol. 2009, 58, 299-312. [CrossRef]

103. Regione Puglia-Servizio Tutela delle Acque. Piano di Tutela Delle Acque (PTA); Regione Puglia: Bari, Italy, 2009.

104. Romanazzi, A.; Gentile, F.; Polemio, M. Modelling and management of a Mediterranean karstic coastal aquifer under the effects of seawater intrusion and climate change. Environ. Earth Sci. 2015, 74, 115-128. [CrossRef]

105. Serio, F.; Miglietta, P.P.; Lamastra, L.; Ficocelli, S.; Intini, F.; De Leo, F.; De Donno, A. Groundwater nitrate contamination and agricultural land use: A grey water footprint perspective in Southern Apulia Region (Italy). Sci. Total Environ. 2018, 645, 1425-1431. [CrossRef] [PubMed]

106. Tulipano, L.; Fidelibus, M.D. Evaluation of overexploitation effects for the Salento coastal karstic aquifer through the interpretation of thermo-conductivity logs in observation wells. In Protection of Groundwater from Pollution and Seawater Intrusion, Proceedings 2 nd Symposium; Bari, Italy, 20-22 September 1999; Futur Grafica Italia: Bari, Italy, 1999.

107. Tulipano, L.; Fidelibus, M.D. Mechanism of groundwater salinisation in a coastal karstic aquifer subject to over-exploitation. In Proceedings of the 17th SWIM, Delft, The Netherlands, 6-10 May 2002.

108. De Waele, J.; Lauritzen, S.E.; Parise, M. On the formation of dissolution pipes in Quaternary coastal calcareous arenites in Mediterranean settings. Earth Surf. Process. Landf. 2011, 36, 143-157. [CrossRef]

109. Margiotta, B. Dinamica Degli Spazi Costieri: Le Cesine (Lecce); Oistros: Lecce, Italy, 1997.

110. Boenzi, F.; Caldara, M.; Pennetta, L.; Simone, O. Environmental aspects related to the physical evolution of some wetlands along the Adriatic coast of Apulia (Southern Italy): A review. J. Coast. Res. 2006, 39, 170-175.

111. Margiotta, S.; Mazzone, F.; Negri, S. Stratigraphic revision of Brindisi-Taranto Plain: Hydrogeological implications. Mem. Descr. Della Carta Geol. D'italia 2010, 90, 165-180.

112. Primavera, M.; Simone, O.; Fiorentino, G.; Caldara, M. The paleoenvironmental study of the Alimini Piccolo Lake enables a reconstruction of Holocene sea level changes in southeast Italy. Holocene 2011, 21, 553-563. [CrossRef] 
113. Margiotta, S.; Negri, S. Alla Ricerca Dell'acqua Perduta; Congedo Editore: Galatina, Italy, 2004.

114. Bossio, A.; Foresi, M.L.; Margiotta, S.; Mazzei, R.; Salvatorini, G.; Donia, F. Stratigrafia neogenico-quaternaria del settore nord-orientale della Provincia di Lecce (con rilevamento geologico alla scala 1:25,000). Geol. Romana 2006, $39,63-88$.

115. Mazzei, R.; Margiotta, S.; Foresi, L.M.; Salvatorini, G.; Riforgiato, F. Biostratigraphy and chronostratigraphy of the Miocene Pietra leccese in the type area of Lecce (Apulia, southern Italy). Boll. Della Soc. Paleontol. Ital. 2009, 48, 129-145.

116. Mastronuzzi, G.; Sansò, P. Holocene coastal dune development and environmental changes in Apulia (southern Italy). Sediment. Geol. 2002, 150, 139-152. [CrossRef]

117. Harding, J.L. Environmental Change during the Holocene in South East Italy: An Integrated Geomorphological and Palynological Investigation; Larix Books: Sheffield, UK, 1999.

118. Novembre, D. Vicende del popolamento e del paesaggio. In Storia Della Puglia; Musca, G., Ed.; Adda Editore: Bari, Italy, 1979; pp. 13-32.

119. Sergi, G.M. Distribuzione delle dimore rurali sorte per necessità di difesa nel Salento. Proceedings XVII Convegno Geografico Italiano, Bari, Italy, 23-29 April 1957; pp. 368-376.

120. Pareto, R. Relazione a Sua Eccellenza il Ministro di agricoltura, industria e commercio. In Sulle Bonificazioni, Risaie ed Irrigazioni del Regno D'italia; Tipografia e litografia degli Ingegneri: Milano, Italy, 1865.

121. Orlando, D. Classificazione Delle Opere di Bonificazione Delle Paludi e dei Terreni Paludosi Della PROVINCIA di Terra D'otranto; Campanella edizioni: Lecce, Italy, 1885.

122. Libertini, L. Relazione sul Progetto di Bonificazione dei Terreni Paludosi Compresi tra Torre Specchia Ruggeri e Torre Rinalda; Tipografia Cooperativa Via Giuseppe Palmieri: Lecce, Italy, 1900.

123. Mainardi, M. La Malaria nel Salento. Salute e Territorio. Paludismo e "Paesaggi Della Malaria" in Provincia di Lecce Nella Prima Metà del XX Secolo; Edizioni Del Grifo: Lecce, Italy, 1998.

124. Mainardi, M. Cantieri di Bonifica; Edizioni Del Grifo: Lecce, Italy, 2017.

125. De Giorgi, C. Cenni di Geografia Fisica Della Provincia di Lecce; Kessinger Publishing LLC: Whitefish, MT, USA, 1884.

126. De Giorgi, C. Descrizione Fisica, Geologica e Idrografica Della Provincia di Lecce; Centro di Studi Salentini: Lecce, Italy, 1922.

127. Marrocco, V.; Sicuro, A.; Zangaro, F.; Pinna, M. First record of the protected species Pinna nobilis (Linnaeus, 1758) in the Aquatina Lagoon (NATURA 2000 site IT9150003, South-East Italian coastline). Nat. Conserv. 2018, 28, 51-59. [CrossRef]

128. Marrocco, V.; Zangaro, F.; Sicuro, A.; Pinna, M. A scaling down mapping of Pinna nobilis (Linnaeus, 1758) through the combination of scientific literature, NATURA 2000, grey literature and citizen science data. Nat. Conserv. 2019, 33, 21-31. [CrossRef]

129. Pinna, M.; Marrocco, V.; Zangaro, F.; Sicuro, A.; Giallongo, G.; Bizhanova, N.; Utebayeva, G.; Marini, G.; Specchia, V. Il bivalve più grande del Mediterraneo, Pinna nobilis, nella Laguna di Acquatina: Indagini preliminari e prospettive. Il Boll. 2018, VIII, 15-18.

130. Pinna, M.; Janzen, S.; Franco, A.; Specchia, V.; Marini, G. Role of habitats and sampling techniques on macroinvertebrate descriptors and ecological indicators: An experiment in a protected Mediterranean lagoon. Ecol. Indic. 2017, 83, 495-503. [CrossRef]

131. Micallef, A.; Foglini, F.; Taviani, M. The submerged paleolandscape of the Maltese Islands: Morphology, evolution and relation to Quaternary environmental change. Mar. Geol. 2013, 335, 129-147. [CrossRef]

132. Curti, L.; Lorenzoni, G.G. Considerazioni sulla vegetazione delle Spunnulate di Castiglione (Lecce). Thalass. Salentina 1969, 3 , 47-66.

133. Schneider, J. Carbonate construction and decomposition by epilitic and endolitic micro-organisms in salt- and freshwater. In Fossil Algae; Flugel, E., Ed.; Springer-Verlag: Berlin/Heidelberg, Germany, 1977; pp. 248-260.

134. Surić, M. Submarine karst of Croatia-Evidence of former lower sea levels. Acta Carsologica 2002, 31, 89-98. [CrossRef]

135. Van Hengstum, P.J.; Scott, D.B.; Gröcke, D.R.; Charette, M.A. Sea level controls sedimentation and environments in coastal caves and sinkholes. Mar. Geol. 2011, 286, 35-50. [CrossRef]

136. Bátori, Z.; Csiky, J.; Farkas, T.; Vojtkó, A.E.; Erdős, L.; Kovács, D.; Wirth, T.; Körmöczi, L.; Vojtkó, A. The conservation value of karst dolines for vascular plants in woodland habitats of Hungary: Refugia and climate change. Int. J. Speleol. 2014, 43, 15-26. [CrossRef]

137. Faccenna, C.; Florindo, F.; Funiciello, R.; Lombardi, S. Tec-tonic setting and Sinkhole Features: Case histories from Western Central Italy. Quat. Proc. 1993, 3, 47-56.

138. Florea, L. Using state-wide GIS data to identify the coincidence between sinkholes and geologic structure. J. Cave Karst Stud. 2005, 67, 120-124.

139. Breg, M. Degradation of dolines on Logasko polje (Slovenia). Acta Carsologica 2007, 36, 223-231. [CrossRef]

140. Closson, D.; Abou Karaki, N. Salt karst and tectonics: Sink-holes development along tension cracks between parallel strike-slip faults, Dead Sea, Jordan. Earth Surf. Process. Landforms 2009, 34, 1408-1421. [CrossRef]

141. Santo, A.; Ascione, A.; Del Prete, S.; Di Crescenzo, G.; Santangelo, N. Collapse sinkholes distribution in the carbonate massifs of central and southern Apennines. Acta Carsologica 2011, 40, 95-112.

142. Closson, D. Structural control of sinkholes and subsidence hazards along the Jordanian Dead Sea coast. Environ. Geol. 2005, 47, 290-301. [CrossRef]

143. Billi, A.; Valle, A.; Brilli, M.; Faccenna, C.; Funiciello, R. Fracture-controlled fluid circulation and dissolutional weathering in sinkhole-prone carbonate rocks from central Italy. J. Struct. Geol. 2007, 29, 385-395. [CrossRef] 
144. Buchignani, V.; D'Amato Avanzi, G.; Giannecchini, R.; Puccinelli, A. Evaporite karst and sinkholes: A synthesis on the case of Camaiore (Italy). Environ. Geol. 2008, 53, 1037-1044. [CrossRef]

145. Wadas, S.H.; Tanner, D.C.; Polom, U.; Krawczyk, C.M. Structural analysis of S-wave seismics around an urban sinkhole: Evidence of enhanced dissolution in a strike-slip fault zone. Nat. Hazards Earth Syst. Sci. 2017, 17, 2335-2350. [CrossRef]

146. Parise, M.; Qiriazi, P.; Sala, S. Natural and anthropogenic hazards in karst areas of Albania. Nat. Hazards Earth Syst. Sci. 2004, 4, 569-581. [CrossRef]

147. Parise, M.; Qiriazi, P.; Sala, S. Evaporite karst of Albania: Main features and cases of environmental degradation. Environ. Geol. 2008, 53, 967-974. [CrossRef]

148. Qiriazi, P.; Parise, M.; Sala, S. Il carsismo nei gessi del territorio albanese. Mem. Dell'istituto Ital. Di Speleol. 2004, 16 , 53-60.

149. Selleri, G.; Sansò, P.; Walsh, N. The karst of Salento region (Apulia, southern Italy): Constraints for management. Acta Carsologica 2003, 32, 19-28. [CrossRef]

150. Alba, A.; Besusso, L.; De Natale, F.; Ingrosso, E.; Lentini, M.; Leucci, G.; Pagliara, V.; Sansò, P.; Selleri, G.; Treglia, G. La pericolosità carsica lungo la fascia costiera di Alliste in Provincia di Lecce. In Proceedings of the Spelaion 2006, Borgo Celano, Italy, 7-10 December 2006; pp. 21-31.

151. Gutierrez, F.; Guerrero, J.; Lucha, P. A genetic classification of sinkholes illustrated from evaporite paleokarst exposures in Spain. Environ. Geol. 2008, 53, 993-1006. [CrossRef]

152. Berest, P. Cases, causes and classifications of craters above salt caverns. Int. J. Rock Mech. Min. 2017, 100, 318-329. [CrossRef]

153. Tharp, T.M. Mechanics of upward propagation of cover-collapse sinkholes. Eng. Geol. 1999, 52, 23-33. [CrossRef]

154. Williams, P. Dolines. In Encyclopedia of Caves and Karst Science; Gunn, J., Ed.; Fitzroy Dearborn: New York, NY, USA, 2004; pp. 304-310.

155. Beck, B. Soil piping and sinkhole failures. In Encyclopedia of Caves, 2nd ed.; Culver, D.C., White, W.B., Eds.; Elsevier Academic Press: Cambridge, MA, USA, 2005; pp. 521-526.

156. Pinna, M.; Marini, G.; Rosati, I.; Neto, J.M.; Patrício, J.; Marques, J.C.; Basset, A. The usefulness of large body-size macroinvertebrates in the rapid ecological assessment of Mediterranean lagoons. Ecol. Indic. 2013, 29, 48-61. [CrossRef]

157. Pinna, M.; Marini, G.; Cristiano, G.; Mazzotta, L.; Vignini, P.; Cicolani, B.; Di Sabatino, A. Influence of aperiodic summer droughts on leaf litter breakdown and macroinvertebrate assemblages: Testing the drying memory in a Central Apennines River (Aterno River, Italy). Hydrobiologia 2016, 782, 111-126. [CrossRef]

158. Di Sabatino, A.; Cristiano, G.; Pinna, M.; Lombardo, P.; Miccoli, F.P.; Marini, G.; Vignini, P.; Cicolani, B. Structure, functional organization and biological traits of macroinvertebrate assemblages from leaf-bags and benthic samples in a third-order stream of Central Apennines (Italy). Ecol. Indic. 2014, 46, 84-91. [CrossRef]

159. Specchia, V.; Janzen, S.; Marini, G.; Pinna, M. The Potential Link between Mobile DNA and the invasiveness of the species. J. RNAi Gene Silenc. 2017, 13, 557-561. 